\title{
Standardized Input for Hanford Environmental Impact Statements - Part I
}

B. A. Napier

May 1981

Prepared for the U.S. Department of Energy under Contract DE-AC06-76RLO 1830

Pacific Northwest Laboratory

Operated for the U.S. Department of Energy

by Battelle Memorial Institute 


\title{
NOTICE
}

This report was prepared as an account of work sponsored by the United States Government. Neither the United States nor the Department of Energy, nor any of their employees, nor any of their contractors, subcontractors, or their employees, makes any warranty, express or implied, or assumes any legal liability or responsibility for the accuracy, completeness or usefulness of any information, apparatus, product or process disclosed, or represents that its use would not infringe privately owned rights.

The views, opinions and conclusions contained in this report are those of the contractor and do not necessarily represent those of the United States Government or the United States Department of Energy.

\author{
PACIFIC NORTHWEST LABORATORY \\ operated by \\ BATTELLE \\ for the \\ UNITED STATES DEPARTMENT OF ENERGY \\ Under Contract DE-AC06-76RLO 1830
}
Printed in the United States of America Available from
National Technical Information Service
United States Department of Commerce 5285 Port Royal Road
Springfield, Virginia 22151

Price: Printed Copy $\$$ $\therefore$ Microfiche $\$ 3.00$

$\begin{array}{cc}\text { •Pages } & \begin{array}{c}\text { NTIS } \\ \text { Selling Price }\end{array} \\ & \\ 001-025 & \$ 4.00 \\ 026-050 & \$ 4.50 \\ 051-075 & \$ 5.25 \\ 076-100 & \$ 6.00 \\ 101-125 & \$ 6.50 \\ 126-150 & \$ 7.25 \\ 151-175 & \$ 8.00 \\ 176-200 & \$ 9.00 \\ 201-225 & \$ 9.25 \\ 226-250 & \$ 9.50 \\ 257-275 & \$ 10.75 \\ 276-300 & \$ 11.00\end{array}$




\title{
33679000553612
}

\author{
STANDARDIZED INPUT FOR \\ HANFORD ENVIRONMENTAL \\ IMPACT STATEMENTS - PART I
}

B. A. Napier

May 1981

Prepared for

the U.S. Department of Energy under Contract DE-AC06-76RLO 1830

Pacific Northwest Laboratory

Richland, Washington 99352 


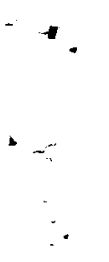

. 


\section{FOREWORD}

This report is Part I of a series of reports on standardized sections and methodologies for environmental impact statements (EIS's) prepared for DOE activities to be conducted at the Hanford site. This report describes current methods used at Hanford for calculating radiation doses to the public from routine and accidental releases of radionuclides to the environment. It is intended as an overview of the methods and a starting point for persons preparing EIS's for locations on the Hanford site. Part II will be added in fiscal year 1981 and will contain the Hanford site description.

Many specific requirements and input parameters required for Hanford environmental dose calculations are given in this report. Dose related values are those of the Hanford Dose Overview Program Report, PNL-3777 (1981). The Hanford Dose Overview Program is intended to assure consistency of Hanford related dose calculations by providing central coordination and review as we 11 as by maintaining a current set of standard Hanford inputs. PNL-3777 will be updated at intervals when necessary. The Overview Program is administered by PNL's Environmental Evaluations Section, Occupational and Environmental Protection Department.

Less detailed information is provided in this report regarding groundwater transport pathway calculations. Such calculations are highly facility and site specific. The Hanford Groundwater Model is maintained by PNL's Hydrologic Systems Section, Water and Land Resources Department. 
CONTENTS

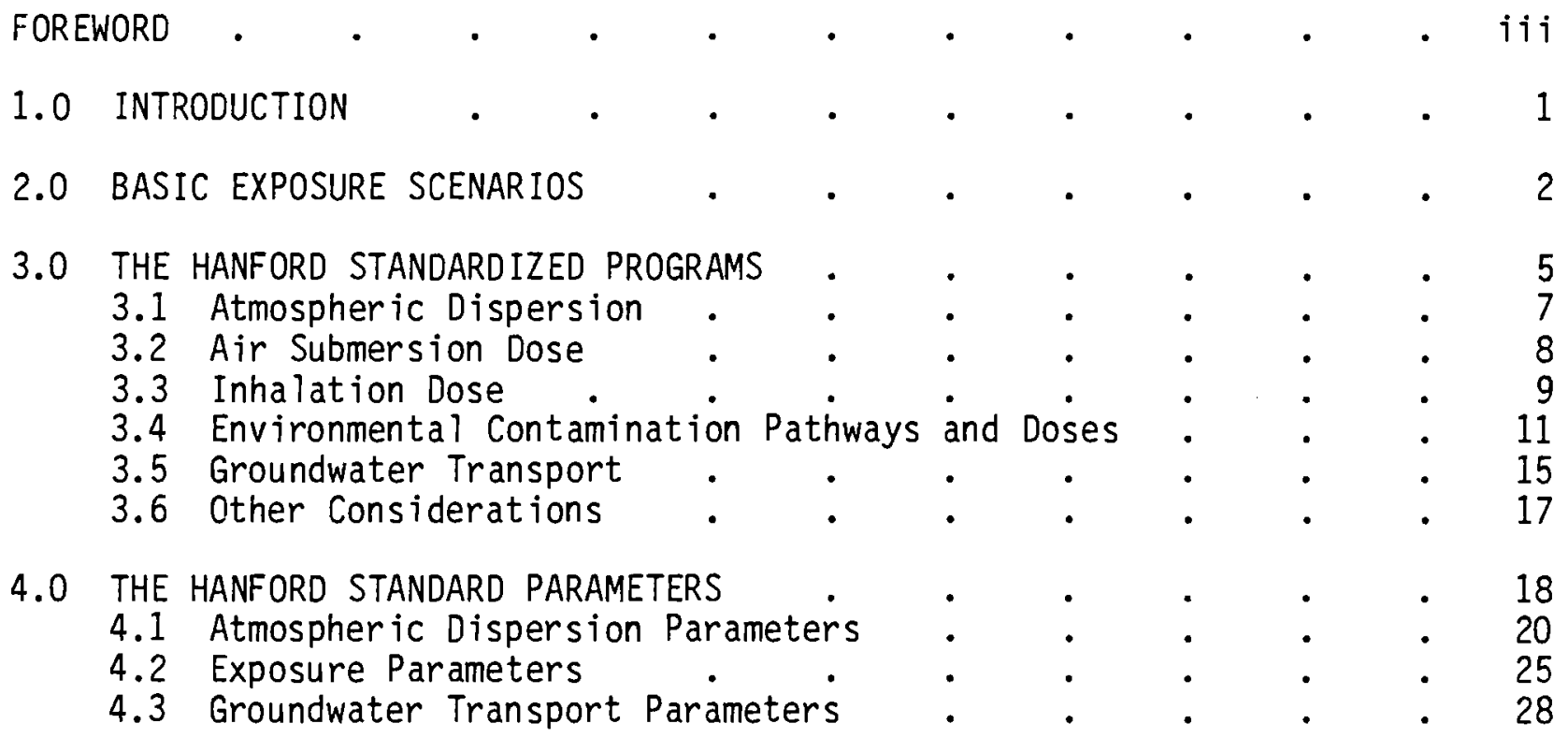

5.0 PROGRAM ACCESS

6.0 REFERENCES .

APPENDIX A - RADIATION DOSE TERMINOLOGY AND DEFINITIONS

- A. 1

v 
FIGURES

1. Computer Programs for Calculating Public Doses

from Routine Airborne Releases of Radionuclides

2. Computer Programs for Calculating Public Doses

from Accidental Airborne Releases of Radionuclides . . . . 4

3. Computer Program for Calculating Public Doses from

Routine or Accidental Liquid Release of Radionuclides

4. Computer Program for Calculating Public Doses from Routine

or Accidental Liquid Release of Radionuclides to Groundwater

5. Computer Program for Calculating Individual Maximum Annual

Dose from Residual Radiation from a Decommissioned Site . . . 5

6. Schematic Diagram of DACRIN Model . . • . . . . . . 11

A.1 Exposure Pathways to Man . . . . . . . . . . A.5

$\underline{\text { TABLES }}$

1. Programs for Calculating Radiation Doses . . . . . 6

2. Standardized Data Libraries . . . . . . . . . . 19

3. Joint Frequency Data for Ground-Level Releases, 100-N Area . . 21

4. Joint Frequency Data for Elevated Releases, 100-N Area . . . 21

5. Joint Frequency Data for Ground-Level Releases, 200 Area . . . . 22

6. Joint Frequency Data for Elevated Releases, 200 Area . • . 22

7. Joint Frequency Data for Ground-Level Releases, 300 Area . . . 24

8. Standard Hanford Terrestrial Exposure Pathway Data . . . . . 26

9. Standard Hanford Aquatic Exposure Pathway Data . . . . . 26

10. General Exposure Pathway Data . • • • • • . 27

11. Computer Program Access and Assistance. . . . . . 30 


\section{STANDARD HANFORD RADIATION DOSE CALCULATION METHODOLOGIES}

\subsection{INTRODUCTION}

Models and computer programs for simulating the environmental behavior of radionuclides in the environment and the resulting radiation dose to humans have been developed over the years by the Environmental Analysis Section staff, Ecological Sciences Department at the Pacific Northwest Laboratory $(P N L)$. Methodologies have evolved for calculating radiation doses from many exposure pathways for any type of release mechanism. Depending on the situation or process being simulated, different sets of computer programs, assumptions, and modeling techniques must be used. This report is a compilation of recommended computer programs and necessary input information for use in calculating doses to members of the general public for environmental impact statements prepared for DOE activities to be conducted on or near the Hanford Reservation.

The Hanford Dose Overview Program, administered by PNL's Environmental Evaluations Section, Occupational and Environmental Protection Department, has established certain standardized requirements for Hanford dose calculations in order to obtain consistent results among various users. Requirements for types of calculations, Hanford specific parameters, and other standardized calculational inputs are specified in the Hanford Dose Overview Program Report, PNL-3777. Values given in this report are those of PNL-3777 as of this writing. PNL-3777 will be updated as revised parameters become available, so it will remain the ultimate source of Standard Hanford parameters.

Many of the computer programs described herein are available to users on the Hanford Reservation on the Boeing Computer Services, Richland, (BCSR) UNIVAC $1100 / 44$, System B. The UNIVAC programs access various data libraries which have been standardized. The other programs are available on PNL computers. All programs and data libraries are maintained by PNL. The computer programs have been separately documented; this chapter summarizes the key points of each model and describes the circumstances for which each would be used. Radiation dose terminology and definitions used in the Hanford Standardized dose programs are given in Appendix A. 


\subsection{BASIC EXPOSURE SCENARIOS}

There are two general catagories of release of radionuclides to the environment: controlled, low-level releases that continue for relatively long periods of time, as occur during normal operation of nuclear facilities; and abrupt, usually accidental, releases. There are also two primary modes of release at Hanford that allow radionuclides to disperse in the environment: releases to the atmosphere and releases to surface water. These release types combine into five basic scenarios for public exposure to radionuclides:

- acute releases to the atmosphere

- chronic (routine) releases to the atmosphere

- acute releases to surface waters

- chronic releases to surface waters

- exposure to residual contamination.

For each of the five basic exposure scenarios there are associated many possible exposure pathways. For example, for an acute release to the atmosphere, a member of the public may be irradiated by the passing cloud of radionuclides, he may inhale some, and some may deposit on the ground and plants around his home resulting in a source of long-term exposure from a short-term release. A set of computer programs has been developed to calculate the dose consequences from all the major exposure pathways from each of the basic release scenarios. These programs are individually described in Section 1.3.

Figures 1 through 5 illustrate the computer programs recommended for use in calculating radiation doses from the basic scenarios for environmental impact statements from activities to be conducted on the Hanford site. These programs are briefly described in Section 3 and are described in detail in the appropriate documentation/users manuals. The input variables required to run each program for the Hanford environs are given in Section 4.

The computer programs suggested for calculating dose to a maximallyexposed individual and to the regional population from a chronic atmospheric release are shown in Figure 1. The programs KRONIC and DACRIN take information about meteorology and population distribution and calculate air submersion and inhalation doses, respectively, for a given release term. A 
population weighted value of the annual average air concentration per unit release of radionuclides, $\left(\bar{X} / Q^{\prime}\right)$ calculated as a byproduct of KRONIC, is used along with information on crops grown locally by the programs FOOD or PABLM to calculate a dose commitment or an accumulated dose from terrestrial pathways.

Figure 2 shows the programs recommended for calculating doses from acute atmospheric releases of radionuclides. The program HADOC uses meteorology and population data to calculate air submersion and inhalation doses. The inhalation doses are based on dose commitment factors precalculated using DACRIN. The program PABLM calculates the accumulated doses resulting from an acute deposition on crops followed by residual environmental contamination.

Figure 3 represents the program flow for releases of contaminated iiquids to the surface waters, for both acute and chronic release modes. PABLM can be used for either acute or chronic mode to calculate doses from irrigated crops, aquatic foods, drinking water, and aquatic recreation. The programs ARRRG and FOOD can be used for chronic releases.

No "direct" pathways to man result from releases of radionuclides to groundwater. Site-specific modeling of the groundwater flow through the local aquifers must first be done. Groundwater modeling is usually performed in two steps. Groundwater flow models such as FE3DGW or VTT are used to determine the groundwater potentials, flow paths, and travel times. Then contaminant transport models like MMT or GETOUT are applied to simulate mass transport and geochemical interactions. Depending on the level of detail required, groundwater codes can be run in from one to three dimensions. Groundwater codes are not considered to be part of the set of standardized Hanford dose codes, but a brief discussion of their interface with the dose codes is included here. Groundwater modeling can generate values of either radionuclide seepage to the Columbia River or contamination levels in well water. The programs PABLM, FOOD, and ARRRG can then be applied as is done for direct releases to surface waters (Figure 4 ). 


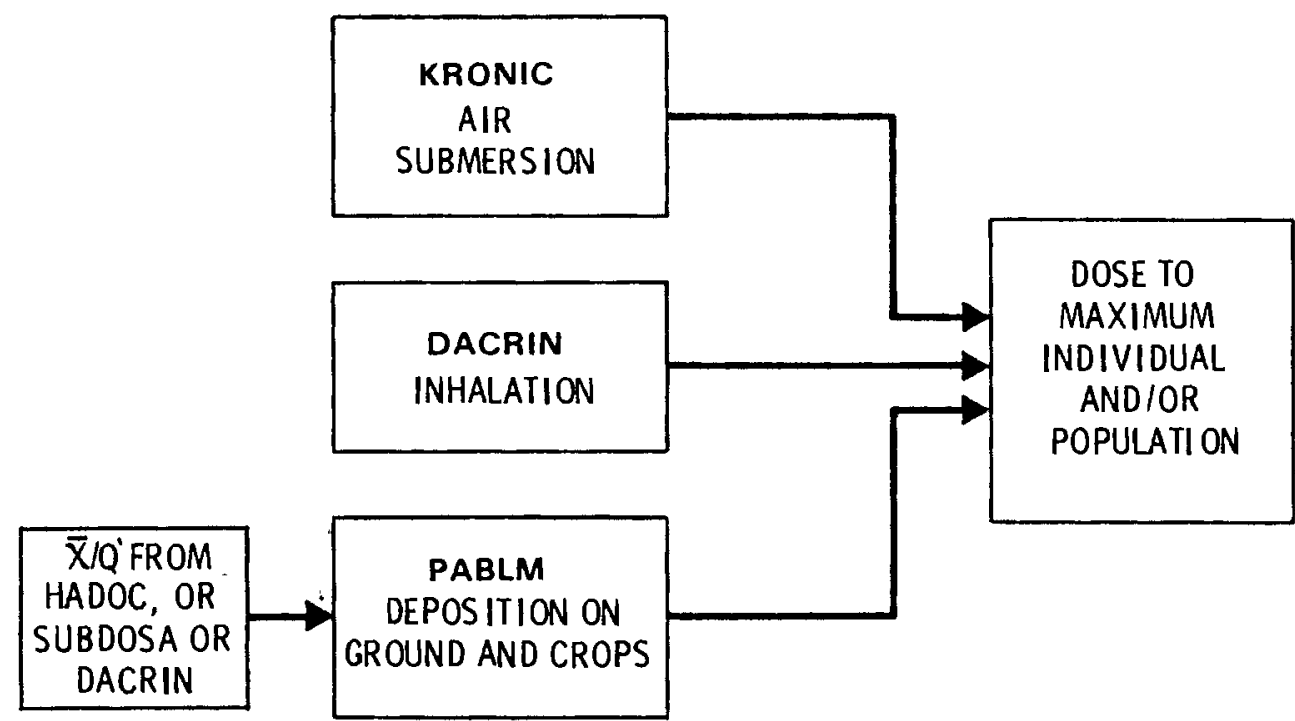

FIGURE 1. Computer Programs for Calculating Public Doses from Routine Airborne Releases of Radionuclides

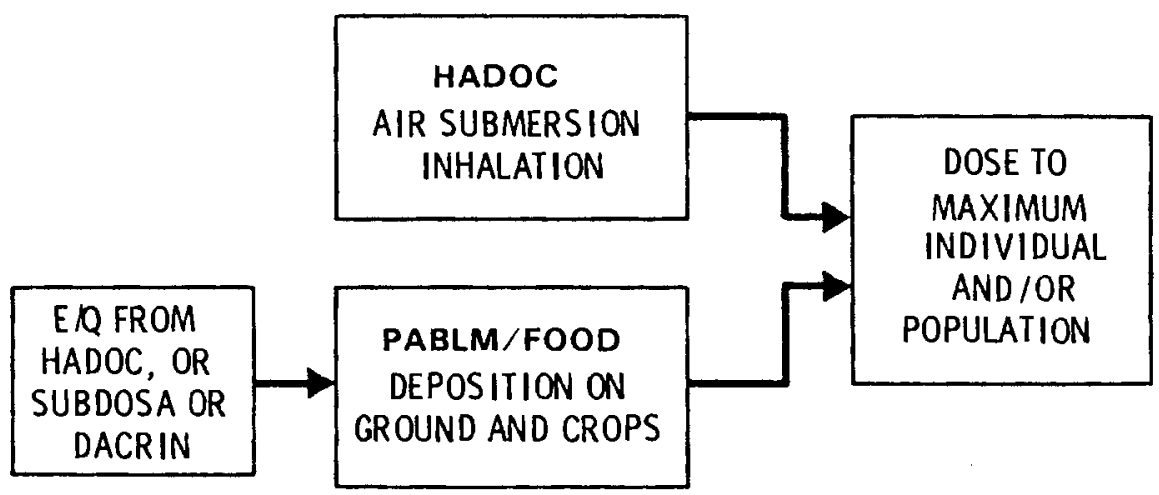

FIGURE 2. Computer Programs for Calculating Public Doses from Accidental Airborne Releases of Radionuclides

\begin{tabular}{|c|c|}
\hline PABLM/FOOD/ \\
ARRRG \\
IRRIGATED CROPS \\
AQUATIC FOODS \\
AQUATIC RECREATION \\
DRINKING WATER
\end{tabular}$\quad$\begin{tabular}{|} 
DOSE TO \\
MAXIMUM \\
INDIVIDUAL \\
AND IOR \\
POPULATION \\
\hline
\end{tabular}

FIGURE 3. Computer Program for Calculating Public Doses from Routine or Accidental Liquid Release of Radionuclides to Surface Waters 


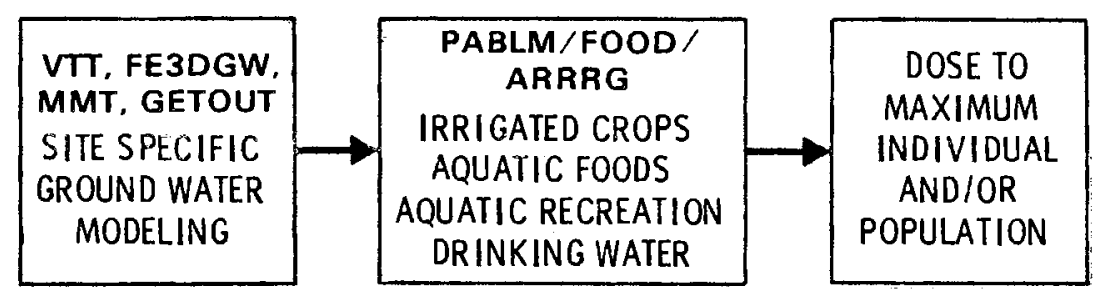

FIGURE 4. Computer Programs for Calculating Public Doses from Routine or Accidental Liquid Release of Radionuclides to Groundwater

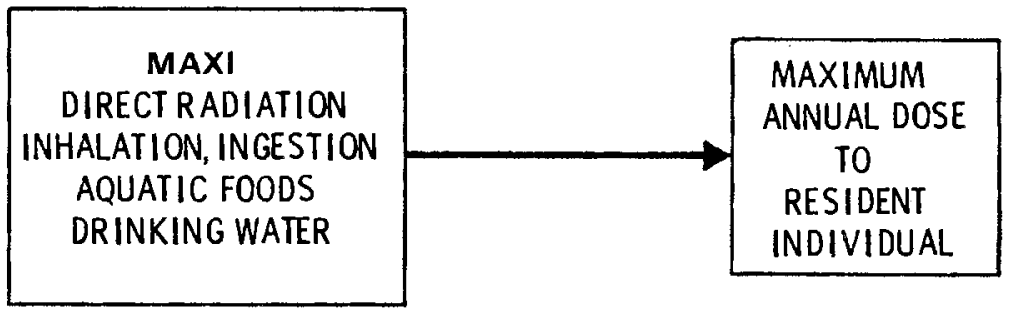

FIGURE 5. Computer Program for Calculating Individual Maximum Annual Dose from Residual Radiation from a Decommissioned Site

Circumstances involving use of decommissioned and decontaminated 1 and or buildings are modeled as shown in Figure 5. The model package MAXI can be used to calculate inhalation dose from resuspended material, direct radiation dose from residual radioactivity, and dose from various ingestion pathways that might result from the proposed action. Recent additions to MAXI also allow consideration of airborne radionuclides from distant sources as well.

\subsection{THE HANFORD STANDARDIZED PROGRAMS}

The computer programs available to Hanford Site users to calculate radiation doses to members of the public are a flexible set intended to cover most radionuclide exposure scenarios. The standardized programs recommended for use on the Hanford Site are listed in Table 1 with a brief description of the type of calculation each performs. Some codes not considered as part of the Hanford dose code group are included as "unstandardized" programs. These 
TABLE 1. Programs for Calculating Radiation Doses

\begin{tabular}{|c|c|c|}
\hline $\begin{array}{l}\text { Standardized } \\
\text { Procrams } \\
\end{array}$ & Type of Calculation & Reference \\
\hline KRONIC* & $\begin{array}{l}\text { One-year air submersion dose from chronic } \\
\text { releases, individual and collective }\end{array}$ & Strenge 1973 \\
\hline SUBDOSA & $\begin{array}{l}\text { one-year individual air submersion doses } \\
\text { from acute release (finite cloud model) }\end{array}$ & Strenge $1975 a$ \\
\hline HADOC* & $\begin{array}{l}\text { One-year individual and collective air sub- } \\
\text { mersion and inhalation dose commitments } \\
\text { from acute releases (semi-infinite } \\
\text { cloud model for external doses) }\end{array}$ & Strenge $1980 \mathrm{a}$ \\
\hline DACR IN* & $\begin{array}{l}\text { Individual and collective inhalation doses } \\
\text { from chronic or acute releases, one-year } \\
\text { doses, dose commitments, and accumulated } \\
\text { doses }\end{array}$ & $\begin{array}{l}\text { Houston } 1974 \\
\text { Strenge } 19750\end{array}$ \\
\hline ARRRG & $\begin{array}{l}\text { Individual and collective doses from con- } \\
\text { taminated water and aquatic foods and } \\
\text { dquatic recreation, one-year dose and } \\
\text { dose commitment }\end{array}$ & Napier 1980a \\
\hline FOOD & $\begin{array}{l}\text { Individual and collective doses from con- } \\
\text { taminated farm products, from either air } \\
\text { deposition or irrigation, one-year dose } \\
\text { and dose commitment }\end{array}$ & Napier $1980 \mathrm{a}$ \\
\hline PABLM* & $\begin{array}{l}\text { A combination of the capabilities of ARRRG } \\
\text { and FOOD to calculate accumulated doses }\end{array}$ & Napier $1980 b$ \\
\hline $\operatorname{MAXI*}$ & $\begin{array}{l}\text { A calculational package to calculate in- } \\
\text { dividual maximum annual dose from residual } \\
\text { radioactivity following nuelear facility } \\
\text { decomissioning }\end{array}$ & $\begin{array}{l}\text { Murphy } 1980 \\
\text { Napier } 1979 \\
\text { Kennedy } 1979\end{array}$ \\
\hline ALLDOS & $\begin{array}{l}\text { A report generator using the output from } \\
\text { SUBDOSA or HADOC, DACRIN, and PABLM }\end{array}$ & Strenge $1980 \mathrm{~b}$ \\
\hline \multicolumn{3}{|c|}{ Unstandardized Programs } \\
\hline$v \pi *$ & $\begin{array}{l}\text { A two-dimensional finite difference } \\
\text { groundwater flow model }\end{array}$ & Re isenauer 1980 \\
\hline FE30GW & $\begin{array}{l}\text { A three-dimensional finite element } \\
\text { groundwater flow mode? }\end{array}$ & Gupta 1980 \\
\hline GETOUT & $\begin{array}{l}\text { A one-dimensional analytical radio- } \\
\text { nuclide groundwater mass transport } \\
\text { model, including radionuelide chain } \\
\text { decay }\end{array}$ & DeMier 1979 \\
\hline MMT* & $\begin{array}{l}\text { A one- or two-dimensional oiscrete- } \\
\text { Parcel-Random-Walk model for mass } \\
\text { transport in groundwater systems, } \\
\text { including radionuclide chain decay }\end{array}$ & An 1strom 1977 \\
\hline CONVERT & $\begin{array}{l}\text { A short code to prepare the output from } \\
\text { the GETOUT program for use with the dose } \\
\text { program PABLM }\end{array}$ & Lidde11 1981 \\
\hline
\end{tabular}


codes and the models they implement are briefly described in the following sections. Full descriptions are given in the pertinent references. Because the atmospheric dispersion models are used in several programs, they are described separately.

\subsection{Atomspher ic Dispersion}

The concentrations of radionuclides released to the atmosphere, either accidentally or routinely, from nuclear facilities are calculated using Gaussian models (Slade 1968). For chronic releases, meteorological data giving the joint frequency of occurrence of wind speed, wind direction, and atmospheric stability, is used with parameters such as release height and plume rise data to estimate the annual average air concentration near the site. The atmospheric concentrations of radionuclides from accidental releases are calculated using the methodology of U.S. Nuclear Regulatory Commission Regulatory Guide 1.3 (USAEC 1974) and of "Meteorology and Atomic Energy" (Slade 1968). For both release types, the vertical dispersion parameter, $\sigma_{z}$, can be evaluated from curves derived from the work of Pasquill (1962) as modified by Gifford (Sagendorff 1977), from Sutton (1953), or from work done at the Hanford Nuclear Reservation (Fuquay 1964). For acute releases, the horizontal dispersion parameter, $\sigma_{y}$, is evaluated in the same manner as $\sigma_{z}$ concentrations are subsequently calculated independent of downwind direction, but again broken into 10 radial intervals. In general, air concentrations are estimated for chronic releases for 16 sectors corresponding to the 16 compass points. Each of these sectors is further divided into ten downwind distances from 0 to $80 \mathrm{~km}$. For chronic releases, horizontal dispersion is determined by averaging within the sector boundaries. These models are for distances close to the release point and for sites with fairly level terrain. Areas with complicated topography or varying wind patterns will be adequately modeled only for distances close to the release point. These models are based on empirical data obtained during experiments that took place at sites with fairly level terrain and for distances relatively close to the point of release. As such, large uncertainties are associated with application of the se models to sites with complicated 
topography or distances downwind of the release point (greater than $10 \mathrm{~km}$ ). These models are used in the computer programs KRONIC (Strenge 1973), SUBDOSA (Strenge 1975a), HADOC (Strenge 1980), and DACRIN (Houston 1974, Strenge 1975b).

\subsection{Air Submersion Dose}

Air submersion dose results from the external exposure to both gamma and beta radiation emitted from airborne radionuclides surrounding the human receptor. The dose is dependent on the type of radiation, energy, and the spatial distribution of radionuclides in the atmosphere, and the duration of the exposure.

KRONIC. The computer program KRONIC (Strenge 1973) is used to calculate air submersion doses from long-term releases to the atmosphere. The beta dose contribution is calculated using a semi-infinite cloud model. This model is used because the range of beta particles in air is short compared to the dimensions of the plume. The gamma dose calculation is more complicated because of the relatively long range of photons in air. To properly determine the gamma contribution, it is necessary to perform a space integration over the plume volume. The gamma dose is calculated as a tissue dose at the body surface, at a depth of $1 \mathrm{~cm}$ and at a depth of $5 \mathrm{~cm}$. The beta and gamma doses are reported separately; however, the beta dose and gamma surface dose may be added and reported as a skin dose. Calculations using KRONIC are normally based on annual releases, thus individual and population doses are reported as annual doses. Release times of less than a year may be used provided corresponding source term and joint frequency wind data are available. The reported doses then correspond to the release time used. If the release persists for periods longer than one year, the one year dose is calculated and then multiplied by the number of years to obtain the accumulated dose.

HADOC. HADOC calculates external dose from air submersion and internal dose from inhalation following acute atmospheric releases of radionuclides. A semi-infinite cloud model is used. Atmospheric dispersion is calculated using the Hanford model with options to determine maximum conditions. Building wake effects and terrain variation may also be considered. Doses calculated are 
one-year doses and dose commitments for both the maximally exposed individual and the regional population. The inhalation doses are calculated using factors derived from the program DACRIN, Section 3.3. External doses are calculated using factors generated by the program SUBDOSA.

SUBDOSA. The computer program SUBDOSA (Strenge 1975a) can also be used to calculate air submersion doses from accidental atmospheric releases of radionuclides. SUBDOSA uses the acute release atmospheric dispersion methodology described in Section 3.1 and a space integration similar to that used in KRONIC instead of the semi-infinite cloud model used in HADOC. Dose results are reported for skin, total body, and male gonads. Corresponding tissue depths are $0.007,1.0$, and $5.0 \mathrm{~cm}$, respectively. Doses are calculated for releases within each of several release time intervals. Up to six time intervals can be allowed and separate radionuclide inventories and atmospheric dispersion conditions can be considered for each time interval. As in KRONIC, the dose results are normally a one-year dose for both the maximum individual and for the regional population.

\subsection{Inhalation Dose}

Radionuclides released to the atmosphere also pose a hazard from inhalaltion. The computer program recommended for the analys is of radiation doses from inhalaltion for operations at Hanford is DACRIN (Houston 1974, Strenge 1975b). The program DACRIN uses the model of the ICRP Task Group on Lung Dynamics (1966) to model radionuclide movements through the respiratory system. Once radionuclides reach the blood stream, the doses to organs other than the lung are calculated using a single exponential retention function (ICRP 1959).

The mode 1 of the respiratory tract adopted by the Task Group on Lung Dynamics forms the general basis for the mathematical models developed to calculate the dose from the inhalation of radionuclides (ICRP 1966). In this model, the respiratory tract is divided into three regions, the nasopharyngeal 
(NP), the tracheobronchial (TB), and the pulmonary (P). The schematic representation of the respiratory tract used in the development of the mathematical model for the deposition and clearance of inhaled radionuclides is shown in Figure 6.

Deposition is assumed to vary with the aerodynamic properties of the aerosol distribution and is described by the three parameters $D_{3}, D_{4}$, and $D_{5}$. These parameters represent the fraction of the inhaled material, $Q_{1}$, initially deposited in the NP, TB, and $P$ regions, respectively. Each of the three regions of deposition are further subdivided into two or more subcompartments. Each subcompartment represents the fraction of material initially in a compartment that is subject to a particular clearance process. This fraction is represented by $f_{k}$, where $k$ indicates the clearance pathway. The quantity of material in the TB region, for example, cleared by process (c) is then represented by the product $f_{c} D_{4} I$.

Values of the $\left(f_{k}\right)$ and the clearance half times $T_{k}$, based on three solubility classes; $D, W$, and $Y$, for each clearance process for the three solubility classes of aerosols used in the code are those suggested by the ICRP (1972). Values of the deposition fractions, $D_{3}, D_{4}$, and $D_{5}$, as function of activity median aerodynamic diameter (AMAD) in the form of a graph, have been published (ICRP 1966). Routines to generate these values directly from the AMAD have been included in the code and yield essentially the same values as those presented by the Task Group for the range of particle size distributions considered by that group.

DACRIN also incorporates the ability to calculate atmospheric concentrations using the Gaussian bivariate normal distribution plume model, described above for acute releases. However, externally calculated dispersion factors may be input instead.

DACRIN has been used to create files of precalculated inhalation dose factors for use with the programs HADOC, MAXI, and ALLDOS.

Limitations to the DACRIN models include those discussed above as limitations on all atmospheric dispersion models. In addition, data are often 


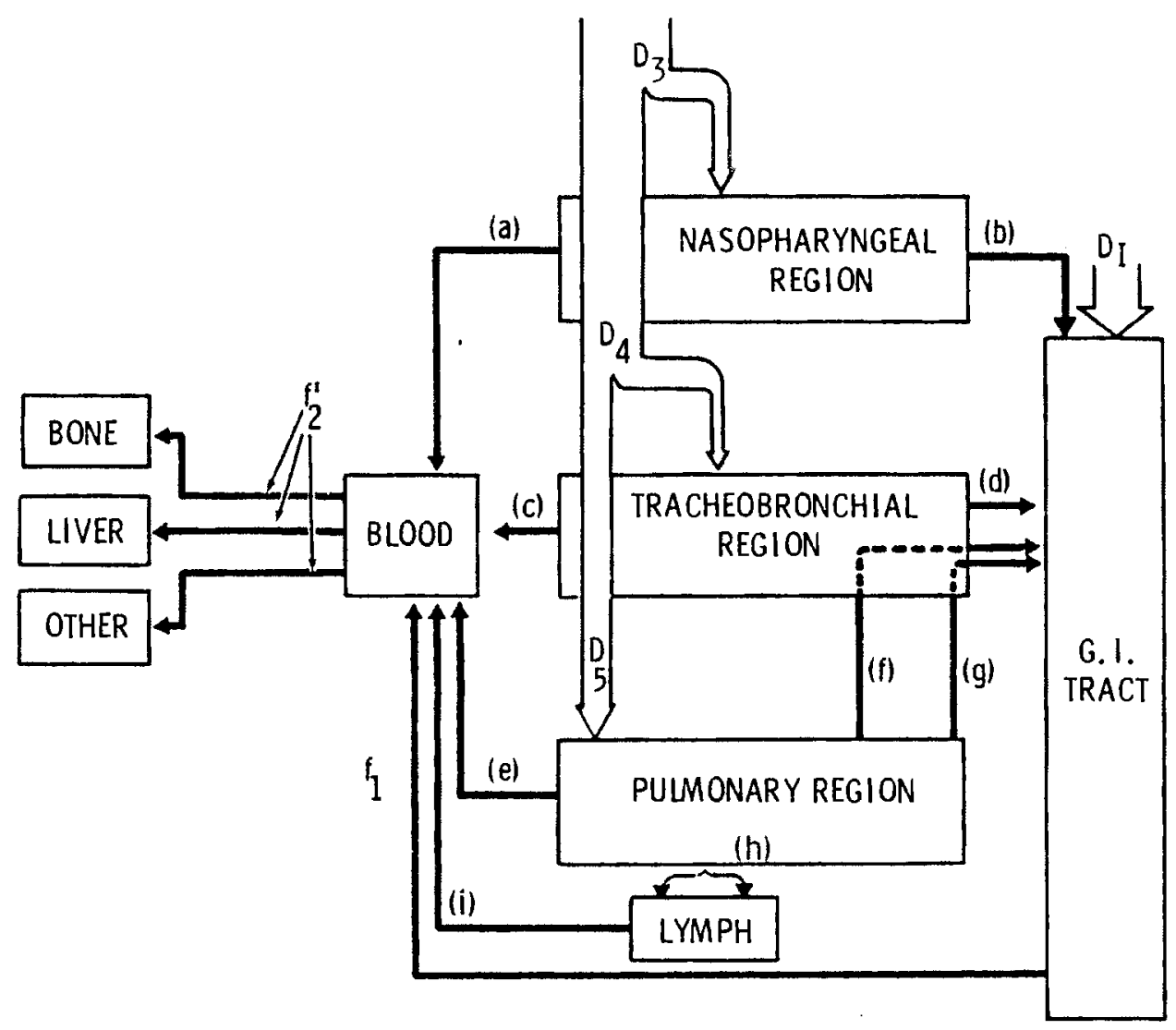

FIGURE 6. Schematic Diagram of DACRIN Mode 1

unavailable on the physical and chemical characterisitcs of the inhaled aerosols. Respirable particles are those of sizes below about 10 microns AMAD, particles much larger than this are not readily inhaled. The chemical solubility of the particles is also of importance in calculating lung clearance times. Conservatively low solubilities can be assumed, but this may cause an overestimation of lung dose.

Doses calculated in DACRIN are dependent upon the values of the release time and dose time used as input. Therefore, the doses that can be calculated include a one-year dose, dose commitment, and accumulated dose for both maximally-exposed individual and population.

\subsection{Environmental Contamination Pathways and Doses}

When radionuclides are released to the atmosphere or to surface waters, they tend to accumulate in the environment. Radionuclides from the air may 
settle on the ground or crops where they can accumulate during the time of the release. If the contamination is in surface waters, it can accumulate in sediments in a lake or river, as well as the water, and also in soils and crops irrigated with the water. These accumulations can result in sources of longterm irradiation of individuals and populations, even from short-lived releases. Sources of dose include direct radiation from contaminated water, sediment, so il and surfaces, and ingestion doses from contaminated drinking water, aquatic food products, terrestrial farm products and farm animal products.

ARRRG. The program ARRRG (Napier 1980a) is used to address aquatic exposure pathways. ARRRG can be used to compute internal dose from ingestion of drinking water, fish, other aquatic animals, or water plants, as well as external dose from swimming, boating, and shoreline exposure. Water concentrations of radionuclides are calculated in ARRRG as a function of nuclide release rate, effluent flow rate, and the mixing and dilution in the receiving waters. Mixing and dilution are characterized by a mixing ratio and a reconcentration factor. Formulas for three of the most common reconcentration factors are included in the program. Concentrations in sediments are calculated from the water concentrations, assuming that the water concentration remains constant throughout the release period. Once the release of radionuclides to the water ceases, removal from the sediments is assumed to be by radioactive decay only. Concentrations of radionuclides in aquatic foods are directly related to the concentrations in the water. Equilibrium ratios between the two concentrations, called bioaccumulation factors, are used in ARRRG to calculate the concentrations. These factors implicitly assume immediate equilibrium between the aquatic biota and the contaminating water; equilibrium is reached at the start of the release and ceases at the end of the release. Concentrations of radionuclides in human drinking water are also related to concentrations in surface waters. Radionuclide removal efficiencies for water treatment plants used in ARRRG are based on extensive experience with the processes used for the cities of Richland and Pasco, Washington, downstream of the Hanford Nuclear Reservation on the Columbia River. Radiation doses calculated from these exposure pathways are based on the simple, single-exponential retention function 
recormended by the International Commission on Radiological Protection (1959). The doses calculated are a one-year dose, and the dose commitment from that one year of exposure or ingestion for both maximum individual and population.

F00D. The program FOOD (Napier 1980a) is used to assess terrestrial exposure pathways. FOOD can be used to compute radiation doses from nine farm or garden crop pathways, five animal product pathways and external exposure. Radionuclides may be deposited on the ground, crops, or animal forage from either atmospheric deposition or irrigation. The model in F00D for estimating the transfer of radionuclides (except for ${ }^{3} \mathrm{H}$ and ${ }^{14} \mathrm{C}$ ) from air or irrigation water to plants through both leaves and soil to food products was derived by Soldat and Harr for a study of the potential doses to people from a nuclear power complex (Soldat 1971). For the atmospheric deposition mechanism, a value of the concentration in air of radionuclides per unit release must be precalculated, as described above, and input to the program. A deposition velocity onto the plant foliage and ground is assumed for the airborne contaminants. Irrigation water concentrations are determined in the program in the same way as for ARRRG. In the absence of specific data for sites where irrigation is used, sprinkler irrigation is assumed, rather than surface irrigation, because the aerial spray produced leads to foliar deposition resulting in higher radionuclide contamination of the plants. For both deposition mechanisms, a plant-to-soil concentration ratio is used to calculate radionuclide concentrations in plants via root uptake. Concentrations of radionculides in farm animal products, such as milk, eggs, or meat, depend on the animals' consumption of contaminated feed, forage, or water.

For the radionuclides tritium and carbon-14, a special model is used: the concentration of these two nuclides in the hydrogen or carbon content, respectively, of environmental media (soil, plants, or animal products) is assumed to have the same specific activity as in the contaminating medium (air or water).

Like ARRRG, FOOD calculates a one-year dose and a dose commitment from one year of exposure for both the maximum individual and population. 
PABLM. It is often more useful to be able to calculate the total integrated lifetime dose from continuous exposure to changing levels of environmental radionuclides. An integrated dose more accurately reflects the true impact of any activity that results in environmental contamination that lasts for more than one year. The computer program PABLM used for this calculation. PABLM combines and enhances the pathway modeling capabilities of both ARRRG and FOOD, additionally allowing consideration of changing levels of environmental contamination with time from continuing deposition and radioactive chain decay with daughter ingrowth. PABLM can be used to calculate a dose commitment from one year of exposure, as well as an integrated dose to either a maximumally exposed individual or populations.

MAXI. The program MAXI is used to calculate a maximum annual dose to an individual from residual contamination after a nuclear facility has been decommissioned and returned to unrestricted use or converted from a nuclear installation. The individual can either be an office worker in a converted building, exposed to inhalation and direct radiation, or someone exposed to pathways as complex as those of a farmer growing crops and living on a former site of a nuclear facility. MAXI uses precalculated factors from versions of ARRRG, FOOD, and DACRIN. Exposure pathways that can be modeled include direct external exposure to contaminated soil or building surfaces, inhalation of resuspended material and ingestion of contaminated foods and aquatic products. The time of the maximum dose rate to individual organs of reference is calculated and the annual dose for that organ is reported. Special options are available to tailor the program to simulate decommissioned reactors, low-level waste burial grounds, or other nuclear material handling facilities.

ALLDOS. When many release scenarios are to be examined for one particular environment, the report generator ALLDOS is available for use with repetative calculations. ALLDOS uses a general inhalation file precalculated using DACRIN as we 11 as a project-specific file created by PABLM. Once the PABLM file has been set up, the convenience code INPREP may be used to prepare the input parameters for ALLDOS. ALLDOS can be used to calculate a one-year dose and either a dose commitment or an accumulated dose, depending on the user's choice during the PABLM setup. 


\subsection{Groundwater Transport}

The methods and computer programs used for calculating radionuclide transport through groundwater are not considered to be integral parts of the standardized Hanford radiation dose methodology, and they are not monitored by the Hanford Dose Overview Program. However, a brief description of some information and programs that are available for use on Hanford environmental impact statements is included in this chapter to provide Hanford EIS preparers with insight into what is available, and where it can be found.

A model of radionuclide transport by groundwater can be considered to consist of three parts; a conceptual model of the local geological, hydrological, and geochemical regime, a hydrologic simulation of groundwater flow patterns, and a mass transport model describing contaminant movement with groundwater. A good description of this interrelationship is given by Silviera (1980). While the models for groundwater flow and mass transport are relatively amenable to computer simulation, they require as input the conceptual mode1. A combination of Hanford-specific groundwater data, the groundwater flow simulation code VTT, and the mass transport code MMT is sometimes referred to as the Hanford Groundwater Model (Wallace 1980). These and other computer codes are discussed in this section. The Hanford data is discussed in Section 4.2 .

VTT. The Variable Thickness Transient (VTT) Groundwater Mode 1 (Reisenauer 1979) is a two dimensional model for simulating saturated groundwater flow. It uses a finite difference solution to the Boussinesq equation, which assumes a two dimensional horizontal view of the groundwater system.

This equation is derived by vertically averaging the three-dimensional equation governing incompressible, Darcian groundwater flow. Thus the independent nonlinear, free-surface boundary condition is incorporated into the governing differential equation. Furthermore, in addition to that flow derived from the storage coefficient, any flux resulting from vertical infiltration from the partially saturated zone above the free surface appears as a source term in the Boussinesq equation. All aquifer properties are represented by their average value over the vertical thickness of saturated 
flow. A significant capability of this numerical formulation of the mathematical model is its ability to handle heterogeneous distributions of hydraulic condictivity and storage coefficient. Another advantage is the ability to simulate muliple connecting aquifers.

The output of this model is either a steady state or a transient groundwater flow potential distribution for the area simulated from which seepage velocities can readily be computed. This output can then be used as input into one of the groundwater transport codes.

FE3DGW. The Finite Element, Three-Dimensional Groundwater Hydrologic model (FE3DGW) (Gupta 1980) is a highly complex code for saturated groundwater flow in heterogenous geology. It uses a finite element solution (Galerkin approach). This code is probably more complex than would be required for most EIS applications, but could be useful for detailed examinations of localized phenomena. The output is, however, similar to that from VTT and can be used in the same way.

GETOUT. The GETOUT code (Demier 1979) is a set of four FORTRAN programs that model the migration of radionuclides from an underground source to a body of water at the ground surface. It can provide a one-dimensional analytical solution, including radioactive chain decay, for simple pulse or band releases. Required input is a description of groundwater flow tubes. Constant flow rate, dispersion, and sorption are assumed. Output consists of reports showing discharge profiles of selected radionuclides and a nuclide discharge summary file. An advantage of the GETOUT code is that a special routine has been prepared that automatically connects the discharge summary file to either of the radiation dose codes PABLM or ALLDOS. The adapter code CONVERT (Liddel1 1980) can be used to control both the groundwater transport and dose codes in one step.

MMT. The Multicomponent Mass Transport (MMT) model (Washburne 1980) uses component-porous media interaction models to simulate migration of constituents in groundwater systems. The constituents may be either pollutants (e.g. radionuclides) or major componenets that are often found in groundwater. MMT uses a method called the Discrete-Parcel-Random-Walk (DPRW) technique for modeling mass transport. The DPRW technique directly simulates the movement 
of constituents through a groundwater flow field, rather than solving a set of equations that mathematically describe the process. MMT can also handle chain radioactive decay, and will accept time-variant leach rate and dispersion information.

Two versions of MMT are available; a one-dimensional and a twodimensional. The two-dimensional version has been applied to Hanford site conditions. An advantage of MMT is that it has been validated against existing conditions at Hanford. A study undertaken with VVT-MMT combined known Hanford tritium concentrations and discharges from 1968 and computed the resultant concentration distribution through 1976. The results showed qualitative agreement through 1976 (Ahlstrom 1977).

\subsection{Other Considerations}

Most of the environmental exposure models and programs were originally designed for calculating doses from effluents from reactors or other nuclear facilities. Therefore, the portions of the programs that consider radionuclide accumulation in the environment may not handle very long-term release scenarios, such as those involving leaching from geologic repositories. A recent study by Schreckhise (1980) has compared a complex soil accumulation model, considering percolation and chemical immobilization of radionuclides, with a modified FOOD model* previously used for calculating doses from long-term irrigation with contaminated water. Schreckhise has shown that continued irrigation for periods of up to 30,000 years could result in soil and plant concentrations for certain radionuclides up to two orders of magnitude higher than those obtained from the FOOD model. It should be noted, however, that attempting to predict doses thousands of years into the future is a tricky proposition at best. The simplicity of the models is in part overridden by the difficulty of selecting parameters and assumptions which reflect real-world conditions. Basing calculations for the distant future on demographic patterns that exist in the present inherently yields highly speculative answers.

* The modification involved assuming that the radionuclide concentrations in the soil come to equilibrium after 50 years of accumulation, accounting for radioactive decay as the only removal mechanism. 
Proper use of ARRRG, FOOD, MAXI, or PABLM requires considerations more detailed even than does use of the atmospheric dispersion models discussed here. Site-specific information about local crop production practices, eating habits, and recreational opportunities are required to correctly set up the input for these codes. Some information on specific and generic sites has been developed, but is not considered to be an integral part of the models. Information on the various parameters required to implement any of the standardized Hanford dose codes is presented in the following section for the Hanford Site in genera 1, and the 100, 200, and 300 Areas in particular. Brief mention is also made to references supplying groundwater data.

\subsection{THE HANFORD STANDARD PARAMETERS}

Much information is required to properly set up and run the standardized Hanford radiation dose calculation programs. Most of the required data have been compiled in computer data libraries automatically accessed by the computer programs. The rest must be individually input directly to the programs. Site specific information required for use in Hanford dose calculations has been compiled by the Hanford Dose Overview Program and is contained in the report PNL-3777. Because this information is subject to revision as site conditions change or as new information becomes available, the Overview Program should be considered the primary source of current information.

Table 2 contains a list of the data libraries maintained on the Boeing Computer Services, Richland, (BCSR) UNIVAC for use with the standardized programs. Most of the libraries are used by more than one program. This assures that the same basic data are used consistently by all the programs. Some other libraries are created on a problem-specific basis to transfer data from one program to another; those are discussed in the relevant program documentation and not included here.

The remainder of the information is directly input to each program as required. It is this information that tailors the program to the site and exposure scenario involved. For applications predicting public dose from activities on the Hanford Site, standardized parameter values for many exposure scenarios have been developed. Atmospheric dispersion parameter values for the $100 \mathrm{~N}, 200$, and 300 areas have been prepared from accumulated 
TABLE 2. Standardized Data Libraries

\begin{tabular}{|c|c|c|}
\hline $\begin{array}{l}\text { Library } \\
\text { Name }\end{array}$ & $\begin{array}{c}\text { Contents of } \\
\text { Library }\end{array}$ & $\begin{array}{l}\text { Referencing } \\
\text { Programs } \\
\end{array}$ \\
\hline $\begin{array}{l}\text { Radionuc lide } \\
\text { master library }\end{array}$ & $\begin{array}{l}\text { The overall master list of } \\
\text { available radionuclides, } \\
\text { radioactive half-lives, and } \\
\text { radioactive decay schemes }\end{array}$ & $\begin{array}{l}\text { DACRIN } \\
\text { ARRRG } \\
\text { FOOD } \\
\text { PABLM } \\
\text { MAXI } \\
\text { HADOC } \\
\text { SUBDOSA } \\
\text { KRONIC }\end{array}$ \\
\hline $\begin{array}{l}\text { Organ data } \\
\text { library }\end{array}$ & $\begin{array}{l}\text { List of biological half- } \\
\text { lives, absorption and } \\
\text { retention factors, and } \\
\text { effective decay energies }\end{array}$ & $\begin{array}{l}\text { DACRIN } \\
\text { ARRRG } \\
\text { FOOD } \\
\text { PABLM } \\
\text { MAXI }\end{array}$ \\
\hline $\begin{array}{l}\text { Food transfer } \\
\text { coefficient } \\
\text { library }\end{array}$ & $\begin{array}{l}\text { Radionuclide-to-food trans- } \\
\text { fer coefficients }\end{array}$ & $\begin{array}{l}\text { FOOD } \\
\text { PABLM } \\
\text { MAXI }\end{array}$ \\
\hline $\begin{array}{l}\text { External dose } \\
\text { factor } \\
\text { library }\end{array}$ & $\begin{array}{l}\text { Dose factors for exposure to } \\
\text { contaminated ground or water }\end{array}$ & $\begin{array}{l}\text { ARRRG } \\
\text { FOOD } \\
\text { PABLM }\end{array}$ \\
\hline $\begin{array}{l}\text { Bioaccumulation } \\
\text { factor libraries }\end{array}$ & $\begin{array}{l}\text { Three versions exist, one } \\
\text { generic, one Hanford specific, } \\
\text { and one with unit drinking } \\
\text { water cleanup factors }\end{array}$ & $\begin{array}{l}\text { ARRRG } \\
\text { PABLM } \\
\text { MAXI }\end{array}$ \\
\hline $\begin{array}{l}\text { Submersion/ } \\
\text { inhalation } \\
\text { dose factor } \\
\text { library }\end{array}$ & $\begin{array}{l}\text { Dose factors derived from the } \\
\text { programs SUBDOSA and DACRIN }\end{array}$ & $\begin{array}{l}\text { HADOC } \\
\text { ALLDOS }\end{array}$ \\
\hline $\begin{array}{l}\text { Inhalation dose } \\
\text { increment factor } \\
\text { library }\end{array}$ & $\begin{array}{l}\text { Incremental annual dose factors } \\
\text { derived from DACRIN }\end{array}$ & MAXI \\
\hline $\begin{array}{l}\text { Energy } \\
\text { probability } \\
\text { library }\end{array}$ & $\begin{array}{l}\text { Photon energies, beta average } \\
\text { energies, and probability } \\
\text { distributions }\end{array}$ & $\begin{array}{l}\text { SUBDOSA } \\
\text { KRONIC }\end{array}$ \\
\hline
\end{tabular}


meteorological data. Popu?ation weighted values of $\bar{x} / Q^{\prime}$ are required for use with some of the pathway analysis programs. These must be calculated using current (or projected) population distributions and the appropriate tables of $\bar{X} / Q^{\prime}$. Dietary and recreational habits in the Hanford environs have been surveyed (Bustad and Terry 1956, Wilson and Essig 1969) and an assumed diet for individuals has been assigned (ERDA 1975, Houston 1979). These and other parameters are discussed below.

\subsection{Atmospher ic Dispersion Parameters}

$100-\mathrm{N}$ Area

The only meteorological data available for the 100 Areas is a set collected at the 100-N Reactor from February, 1970 through January 1971. Information on the joint frequency of occurrence of windspeed, direction, and stability class is available for ground level and 61 meter elevations. This information is presented in Tables 3 and 4 , respectively. Values of atmospheric concentration per unit release $\left(\bar{x} / Q^{\prime}\right)$ are available in the Hanford Annual Report (Houston 1979) for the ground-level releases. Population distributions around the $\mathrm{N}$ reactor are available in the Annual Report or in Yandon, Burlison, and Rau, 1980.

The maximally-exposed individual from $100-\mathrm{N}$ is assumed to reside $8.8 \mathrm{~km}$ (5.5 miles) northwest. This is the Hanford boundary location closest to $100-N$. For a chronic ground-level release the annual average $\bar{X} / Q^{\prime}$ at this location is $1.6 \times 10^{-7} \mathrm{sec} / \mathrm{m}^{3}$. For an acute ground-level release, the time integrated air concentration per unit of activity released, $E / Q$ is $3.0 \times 10^{-5} \mathrm{sec} / \mathrm{m}^{3}$.

\section{Areas}

Meteorological data has been collected at the Hanford Meteorological Station, near 200 West Area, for the past 30 years. Table 5 presents the annual average joint frequency data for essentially ground level (16 m), averaged over 1973 to 1975. Table 6 contains $61 \mathrm{~m}$ elevation joint frequency data averaged over the years 1950 through 1970. Monthly and seasonal averages are also available from the author. Values of $\bar{X} / Q^{\prime}$ in $\mathrm{sec} / \mathrm{m}^{3}$ are available in 
TABLE 3. Joint Frequency Data for Ground-Level Releases, 100-N Area

\begin{tabular}{|c|c|c|c|c|c|c|c|c|c|c|c|c|c|c|c|c|c|}
\hline \multirow[t]{2}{*}{$\begin{array}{c}\text { Stability } \\
\text { Class } \\
\end{array}$} & \multirow{2}{*}{ 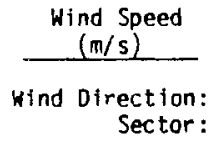 } & \multicolumn{16}{|c|}{ Percent of Time Wind is of Specified Direction, Speed, and Stability } \\
\hline & & $\begin{array}{l}\text { NNE } \\
\text { SSH } \\
\end{array}$ & $\begin{array}{l}\text { NE } \\
\text { SW }\end{array}$ & $\begin{array}{l}\text { ENE } \\
\text { WSW }\end{array}$ & $\begin{array}{l}E \\
W \\
\end{array}$ & $\begin{array}{l}\text { ESE } \\
\text { WNW } \\
\end{array}$ & $\begin{array}{l}\text { SE } \\
\text { NW }\end{array}$ & $\begin{array}{l}\text { SSE } \\
\text { NNH } \\
\end{array}$ & $\begin{array}{l}S \\
N \\
\end{array}$ & $\begin{array}{l}\text { SSW } \\
\text { NNE }\end{array}$ & $\begin{array}{l}S W \\
N E \\
\end{array}$ & $\begin{array}{l}\text { WSW } \\
\text { ENE }\end{array}$ & $\begin{array}{l}W \\
E\end{array}$ & $\begin{array}{l}\text { WNH } \\
\text { ESE } \\
\end{array}$ & $\begin{array}{l}\mathrm{NW} \\
\mathrm{SE} \\
\end{array}$ & $\begin{array}{l}\text { NNW } \\
\text { SSE }\end{array}$ & $\begin{array}{l}n \\
S \\
\end{array}$ \\
\hline $\begin{array}{r}\text { Hanf ord vS } \\
\text { MS } \\
0 \\
B\end{array}$ & $\begin{array}{l}0.78 \\
0.78 \\
0.78 \\
0.78\end{array}$ & $\begin{array}{l}.45 \\
.43 \\
.20 \\
.14\end{array}$ & $\begin{array}{l}.38 \\
.41 \\
.23 \\
.12\end{array}$ & $\begin{array}{l}.36 \\
.39 \\
.24 \\
.15\end{array}$ & $\begin{array}{l}.44 \\
.54 \\
.34 \\
.22\end{array}$ & $\begin{array}{l}.37 \\
.36 \\
.27 \\
.16\end{array}$ & $\begin{array}{l}.34 \\
.35 \\
.19 \\
.07\end{array}$ & $\begin{array}{l}.31 \\
.32 \\
.15 \\
.08\end{array}$ & $\begin{array}{l}.36 \\
.31 \\
.11 \\
.06\end{array}$ & $\begin{array}{l}.36 \\
.33 \\
.14 \\
.06\end{array}$ & $\begin{array}{l}.44 \\
.62 \\
.24 \\
.09\end{array}$ & $\begin{array}{l}.54 \\
.81 \\
.34 \\
.23\end{array}$ & $\begin{array}{l}.58 \\
.77 \\
.43 \\
.33\end{array}$ & $\begin{array}{l}.55 \\
.60 \\
.34 \\
.38\end{array}$ & $\begin{array}{l}.52 \\
.65 \\
.37 \\
.45\end{array}$ & $\begin{array}{l}.52 \\
.65 \\
.35 \\
.44\end{array}$ & $\begin{array}{l}.48 \\
.51 \\
.26 \\
.22\end{array}$ \\
\hline $\begin{array}{l}\text { VS } \\
\text { MS } \\
D \\
B\end{array}$ & $\begin{array}{l}2.5 \\
2.5 \\
2.5 \\
2.5\end{array}$ & $\begin{array}{l}.37 \\
.65 \\
.28 \\
.43\end{array}$ & $\begin{array}{l}.39 \\
.61 \\
.22 \\
.27\end{array}$ & $\begin{array}{l}.56 \\
.80 \\
.22 \\
.39\end{array}$ & $\begin{array}{l}.84 \\
.90 \\
.26 \\
.38\end{array}$ & $\begin{array}{l}.70 \\
.80 \\
.32 \\
.36\end{array}$ & $\begin{array}{l}.54 \\
.51 \\
.22 \\
.22\end{array}$ & $\begin{array}{l}.35 \\
.42 \\
.13 \\
.16\end{array}$ & $\begin{array}{l}.22 \\
.41 \\
.07 \\
.07\end{array}$ & $\begin{array}{l}.29 \\
.53 \\
.11 \\
.09\end{array}$ & $\begin{array}{r}1.02 \\
2.04 \\
.43 \\
.36\end{array}$ & $\begin{array}{r}.95 \\
1.91 \\
.58 \\
.23\end{array}$ & $\begin{array}{r}.51 \\
1.44 \\
.68 \\
.21\end{array}$ & $\begin{array}{r}.30 \\
1.03 \\
.53 \\
.23\end{array}$ & $\begin{array}{l}.33 \\
.69 \\
.35 \\
.21\end{array}$ & $\begin{array}{l}.34 \\
.61 \\
.32 \\
.33\end{array}$ & $\begin{array}{l}.35 \\
.39 \\
.25 \\
.35\end{array}$ \\
\hline $\begin{array}{c}V S \\
M S \\
D \\
B\end{array}$ & $\begin{array}{l}4.5 \\
4.5 \\
4.5 \\
4.5\end{array}$ & $\begin{array}{l}.01 \\
.18 \\
.09 \\
.11\end{array}$ & $\begin{array}{l}.02 \\
.12 \\
.07 \\
.05\end{array}$ & $\begin{array}{l}.11 \\
.12 \\
.03 \\
.06\end{array}$ & $\begin{array}{l}.04 \\
.08 \\
.03 \\
.04\end{array}$ & $\begin{array}{l}.16 \\
.23 \\
.11 \\
.10\end{array}$ & $\begin{array}{l}.18 \\
.24 \\
.07 \\
.08\end{array}$ & $\begin{array}{l}.05 \\
.20 \\
.06 \\
.06\end{array}$ & $\begin{array}{l}.04 \\
.31 \\
.06 \\
.08\end{array}$ & $\begin{array}{l}.00 \\
.39 \\
.12 \\
.08\end{array}$ & $\begin{array}{r}.24 \\
1.21 \\
.20 \\
.13\end{array}$ & $\begin{array}{r}.20 \\
1.81 \\
.32 \\
.11\end{array}$ & $\begin{array}{r}.20 \\
2.08 \\
.40 \\
.20\end{array}$ & $\begin{array}{l}.03 \\
.88 \\
.25 \\
.17\end{array}$ & $\begin{array}{l}.02 \\
.33 \\
.15 \\
.11\end{array}$ & $\begin{array}{l}.01 \\
.13 \\
.13 \\
.09\end{array}$ & $\begin{array}{l}.00 \\
.06 \\
.08 \\
.06\end{array}$ \\
\hline $\begin{array}{c}\text { VS } \\
\text { MS } \\
\text { D } \\
B\end{array}$ & $\begin{array}{l}6.9 \\
6.9 \\
6.9 \\
6.9\end{array}$ & $\begin{array}{l}.00 \\
.10 \\
.06 \\
.04\end{array}$ & $\begin{array}{l}.00 \\
.00 \\
.02 \\
.00\end{array}$ & $\begin{array}{l}.00 \\
.00 \\
.00 \\
.00\end{array}$ & $\begin{array}{l}.00 \\
.00 \\
.00 \\
.00\end{array}$ & $\begin{array}{l}.01 \\
.04 \\
.02 \\
.04\end{array}$ & $\begin{array}{l}.02 \\
.10 \\
.07 \\
.03\end{array}$ & $\begin{array}{l}.00 \\
.08 \\
.02 \\
.01\end{array}$ & $\begin{array}{l}.00 \\
.17 \\
.04 \\
.05\end{array}$ & $\begin{array}{l}.00 \\
.28 \\
.06 \\
.04\end{array}$ & $\begin{array}{l}.00 \\
.31 \\
.14 \\
.13\end{array}$ & $\begin{array}{l}.04 \\
.54 \\
.16 \\
.10\end{array}$ & $\begin{array}{r}.07 \\
1.57 \\
.42 \\
.16\end{array}$ & $\begin{array}{l}.02 \\
.80 \\
.38 \\
.15\end{array}$ & $\begin{array}{l}.00 \\
.20 \\
.11 \\
.07\end{array}$ & $\begin{array}{l}.00 \\
.06 \\
.05 \\
.12\end{array}$ & $\begin{array}{l}.00 \\
.04 \\
.03 \\
.05\end{array}$ \\
\hline $\begin{array}{c}\text { VS } \\
\text { MS } \\
D \\
B\end{array}$ & $\begin{array}{l}9.5 \\
9.5 \\
9.5 \\
9.5\end{array}$ & $\begin{array}{l}.00 \\
.13 \\
.14 \\
.10\end{array}$ & $\begin{array}{l}.00 \\
.01 \\
.06 \\
.01\end{array}$ & $\begin{array}{l}.00 \\
.00 \\
.00 \\
.00\end{array}$ & $\begin{array}{l}.00 \\
.00 \\
.00 \\
.00\end{array}$ & $\begin{array}{l}.00 \\
.00 \\
.00 \\
.00\end{array}$ & $\begin{array}{l}.00 \\
.01 \\
.01 \\
.01\end{array}$ & $\begin{array}{l}.00 \\
.02 \\
.02 \\
.00\end{array}$ & $\begin{array}{l}.00 \\
.05 \\
.04 \\
.01\end{array}$ & $\begin{array}{l}.00 \\
.19 \\
.08 \\
.05\end{array}$ & $\begin{array}{l}.02 \\
.42 \\
.21 \\
.14\end{array}$ & $\begin{array}{l}.01 \\
.26 \\
.15 \\
.06\end{array}$ & $\begin{array}{r}.01 \\
1.07 \\
.74 \\
.25\end{array}$ & $\begin{array}{r}.00 \\
1.04 \\
.89 \\
.44\end{array}$ & $\begin{array}{l}.00 \\
.15 \\
.21 \\
.18\end{array}$ & $\begin{array}{l}.00 \\
.10 \\
.11 \\
.06\end{array}$ & $\begin{array}{l}.00 \\
.02 \\
.04 \\
.03\end{array}$ \\
\hline $\begin{array}{c}\text { VS } \\
\text { MS } \\
D \\
B\end{array}$ & $\begin{array}{l}12.5 \\
12.5 \\
12.5 \\
12.5\end{array}$ & $\begin{array}{l}.00 \\
.00 \\
.01 \\
.04\end{array}$ & $\begin{array}{l}.00 \\
.01 \\
.00 \\
.00\end{array}$ & $\begin{array}{l}.00 \\
.00 \\
.00 \\
.00\end{array}$ & $\begin{array}{l}.00 \\
.00 \\
.00 \\
.00\end{array}$ & $\begin{array}{l}.00 \\
.00 \\
.00 \\
.00\end{array}$ & $\begin{array}{l}.00 \\
.00 \\
.00 \\
.00\end{array}$ & $\begin{array}{l}.00 \\
.00 \\
.01 \\
.00\end{array}$ & $\begin{array}{l}.00 \\
.00 \\
.00 \\
.00\end{array}$ & $\begin{array}{l}.00 \\
.00 \\
.00 \\
.00\end{array}$ & $\begin{array}{l}.00 \\
.06 \\
.05 \\
.01\end{array}$ & $\begin{array}{l}.00 \\
.03 \\
.00 \\
.01\end{array}$ & $\begin{array}{l}.00 \\
.10 \\
.31 \\
.17\end{array}$ & $\begin{array}{l}.00 \\
.20 \\
.20 \\
.17\end{array}$ & $\begin{array}{l}.00 \\
.01 \\
.02 \\
.03\end{array}$ & $\begin{array}{l}.00 \\
.01 \\
.01 \\
.01\end{array}$ & $\begin{array}{l}.00 \\
.00 \\
.01 \\
.01\end{array}$ \\
\hline
\end{tabular}

TABLE 4. Joint Frequency Data for Elevated Releases, 100-N Area

\begin{tabular}{|c|c|c|c|c|c|c|c|c|c|c|c|c|c|c|c|c|c|}
\hline \multirow[t]{2}{*}{$\begin{array}{c}\text { Stability } \\
\text { Class }\end{array}$} & \multirow{2}{*}{ 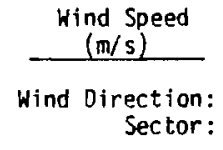 } & \multicolumn{11}{|c|}{ Percent of Time Wind is of Spec if ied Direction, } & \multicolumn{3}{|c|}{ Speed, and Stability } & \multirow[b]{2}{*}{$\begin{array}{l}\text { NNW } \\
\text { SSE }\end{array}$} & \multirow[b]{2}{*}{$\begin{array}{l}N \\
S \\
\end{array}$} \\
\hline & & $\begin{array}{l}\text { NME } \\
\text { SSW } \\
\end{array}$ & $\begin{array}{l}\text { NE } \\
\text { SW }\end{array}$ & $\begin{array}{l}\text { ENE } \\
\text { WSW } \\
\end{array}$ & $\begin{array}{l}E \\
W \\
\end{array}$ & $\begin{array}{l}\text { ESE } \\
\text { WNW } \\
\end{array}$ & $\begin{array}{l}\text { SE } \\
\text { NW }\end{array}$ & $\begin{array}{l}\text { SSE } \\
\text { NNWW } \\
\end{array}$ & $\begin{array}{r}S \\
N \\
\end{array}$ & $\begin{array}{l}\text { SSH } \\
\text { NNE } \\
\end{array}$ & $\begin{array}{r}\mathrm{SW} \\
\mathrm{NE} \\
\end{array}$ & $\begin{array}{l}\text { WSW } \\
\text { ENE } \\
\end{array}$ & $\begin{array}{l}W \\
E\end{array}$ & $\begin{array}{l}\text { WNW } \\
\text { ESE }\end{array}$ & $\begin{array}{l}N H \\
S E \\
\end{array}$ & & \\
\hline $\begin{array}{r}\text { VS } \\
\text { MS } \\
\text { D } \\
\text { B }\end{array}$ & $\begin{array}{l}0.78 \\
0.78 \\
0.78 \\
0.78\end{array}$ & $\begin{array}{l}.38 \\
.33 \\
.21 \\
.46\end{array}$ & $\begin{array}{l}.46 \\
.45 \\
.23 \\
.29\end{array}$ & $\begin{array}{l}.47 \\
.47 \\
.31 \\
.19\end{array}$ & $\begin{array}{l}.53 \\
.54 \\
.33 \\
.30\end{array}$ & $\begin{array}{l}.42 \\
.52 \\
.31 \\
.20\end{array}$ & $\begin{array}{l}.41 \\
.45 \\
.28 \\
.18\end{array}$ & $\begin{array}{l}.27 \\
.33 \\
.20 \\
.11\end{array}$ & $\begin{array}{l}.33 \\
.33 \\
.15 \\
.11\end{array}$ & $\begin{array}{l}.31 \\
.30 \\
.14 \\
.12\end{array}$ & $\begin{array}{l}.28 \\
.40 \\
.19 \\
.27\end{array}$ & $\begin{array}{l}.30 \\
.34 \\
.26 \\
.40\end{array}$ & $\begin{array}{l}.34 \\
.40 \\
.34 \\
.46\end{array}$ & $\begin{array}{l}.35 \\
.41 \\
.35 \\
.50\end{array}$ & $\begin{array}{l}.36 \\
.37 \\
.30 \\
.50\end{array}$ & $\begin{array}{l}.24 \\
.40 \\
.22 \\
.56\end{array}$ & $\begin{array}{l}.30 \\
.37 \\
.20 \\
.54\end{array}$ \\
\hline $\begin{array}{l}\text { VS } \\
\text { MS } \\
\text { D } \\
\text { B }\end{array}$ & $\begin{array}{l}2.5 \\
2.5 \\
2.5 \\
2.5\end{array}$ & $\begin{array}{r}.31 \\
.48 \\
.22 \\
1.57\end{array}$ & $\begin{array}{l}.43 \\
.49 \\
.17 \\
.71\end{array}$ & $\begin{array}{l}.58 \\
.68 \\
.23 \\
.56\end{array}$ & $\begin{array}{l}.62 \\
.90 \\
.26 \\
.77\end{array}$ & $\begin{array}{l}.55 \\
.67 \\
.33 \\
.93\end{array}$ & $\begin{array}{l}.42 \\
.61 \\
.28 \\
.82\end{array}$ & $\begin{array}{l}.39 \\
.37 \\
.16 \\
.43\end{array}$ & $\begin{array}{l}.36 \\
.34 \\
.10 \\
.32\end{array}$ & $\begin{array}{l}.31 \\
.30 \\
.10 \\
.44\end{array}$ & $\begin{array}{r}.39 \\
.55 \\
.22 \\
1.11\end{array}$ & $\begin{array}{r}.52 \\
1.09 \\
.46 \\
1.01\end{array}$ & $\begin{array}{r}.94 \\
1.65 \\
.60 \\
.59\end{array}$ & $\begin{array}{r}.97 \\
1.56 \\
.53 \\
.42\end{array}$ & $\begin{array}{l}.63 \\
.82 \\
.37 \\
.42\end{array}$ & $\begin{array}{l}.32 \\
.42 \\
.29 \\
.62\end{array}$ & $\begin{array}{l}.22 \\
.29 \\
.16 \\
.91\end{array}$ \\
\hline $\begin{array}{r}\text { VS } \\
\text { MS } \\
\text { D } \\
\text { B }\end{array}$ & $\begin{array}{l}4.5 \\
4.5 \\
4.5 \\
4.5\end{array}$ & $\begin{array}{l}.07 \\
.20 \\
.11 \\
.57\end{array}$ & $\begin{array}{l}.06 \\
.10 \\
.07 \\
.33\end{array}$ & $\begin{array}{l}.09 \\
.12 \\
.03 \\
.18\end{array}$ & $\begin{array}{l}.08 \\
.16 \\
.02 \\
.18\end{array}$ & $\begin{array}{l}.13 \\
.26 \\
.13 \\
.29\end{array}$ & $\begin{array}{l}.19 \\
.22 \\
.07 \\
.36\end{array}$ & $\begin{array}{l}.12 \\
.14 \\
.03 \\
.29\end{array}$ & $\begin{array}{l}.06 \\
.17 \\
.03 \\
.22\end{array}$ & $\begin{array}{l}.07 \\
.27 \\
.06 \\
.27\end{array}$ & $\begin{array}{l}.07 \\
.50 \\
.10 \\
.92\end{array}$ & $\begin{array}{r}.13 \\
1.21 \\
.19 \\
.52\end{array}$ & $\begin{array}{r}.34 \\
2.16 \\
.50 \\
.54\end{array}$ & $\begin{array}{r}.33 \\
1.54 \\
.29 \\
.49\end{array}$ & $\begin{array}{l}.10 \\
.55 \\
.13 \\
.26\end{array}$ & $\begin{array}{l}.04 \\
.17 \\
.14 \\
.15\end{array}$ & $\begin{array}{l}.05 \\
.10 \\
.09 \\
.17\end{array}$ \\
\hline $\begin{array}{r}\text { VS } \\
\text { MS } \\
D \\
\text { B }\end{array}$ & $\begin{array}{l}6.9 \\
6.9 \\
6.9 \\
6.9\end{array}$ & $\begin{array}{l}.01 \\
.15 \\
.11 \\
.21\end{array}$ & $\begin{array}{l}.00 \\
.02 \\
.01 \\
.07\end{array}$ & $\begin{array}{l}.01 \\
.00 \\
.00 \\
.02\end{array}$ & $\begin{array}{l}.00 \\
.00 \\
.00 \\
.01\end{array}$ & $\begin{array}{l}.02 \\
.06 \\
.03 \\
.08\end{array}$ & $\begin{array}{l}.05 \\
.12 \\
.06 \\
.16\end{array}$ & $\begin{array}{l}.03 \\
.09 \\
.04 \\
.03\end{array}$ & $\begin{array}{l}.01 \\
.14 \\
.01 \\
.04\end{array}$ & $\begin{array}{l}.01 \\
.18 \\
.05 \\
.15\end{array}$ & $\begin{array}{l}.01 \\
.30 \\
.11 \\
.39\end{array}$ & $\begin{array}{l}.05 \\
.54 \\
.18 \\
.25\end{array}$ & $\begin{array}{r}.15 \\
1.83 \\
.34 \\
.36\end{array}$ & $\begin{array}{r}.14 \\
1.31 \\
.38 \\
.42\end{array}$ & $\begin{array}{l}.00 \\
.28 \\
.14 \\
.17\end{array}$ & $\begin{array}{l}.01 \\
.08 \\
.07 \\
.09\end{array}$ & $\begin{array}{l}.01 \\
.04 \\
.02 \\
.07\end{array}$ \\
\hline $\begin{array}{r}\text { VS } \\
\text { MS } \\
D \\
B\end{array}$ & $\begin{array}{l}9.5 \\
9.5 \\
9.5 \\
9.5\end{array}$ & $\begin{array}{l}.00 \\
.19 \\
.29 \\
.30\end{array}$ & $\begin{array}{l}.00 \\
.07 \\
.07 \\
.08\end{array}$ & $\begin{array}{l}.00 \\
.00 \\
.01 \\
.00\end{array}$ & $\begin{array}{l}.00 \\
.00 \\
.00 \\
.00\end{array}$ & $\begin{array}{l}.00 \\
.01 \\
.00 \\
.00\end{array}$ & $\begin{array}{l}.01 \\
.11 \\
.06 \\
.04\end{array}$ & $\begin{array}{l}.02 \\
.09 \\
.04 \\
.01\end{array}$ & $\begin{array}{l}.01 \\
.13 \\
.02 \\
.02\end{array}$ & $\begin{array}{l}.00 \\
.20 \\
.07 \\
.09\end{array}$ & $\begin{array}{l}.00 \\
.50 \\
.17 \\
.40\end{array}$ & $\begin{array}{l}.00 \\
.36 \\
.19 \\
.18\end{array}$ & $\begin{array}{r}.07 \\
1.66 \\
.55 \\
.42\end{array}$ & $\begin{array}{r}.07 \\
2.18 \\
1.15 \\
.90\end{array}$ & $\begin{array}{l}.00 \\
.36 \\
.37 \\
.33\end{array}$ & $\begin{array}{l}.00 \\
.06 \\
.07 \\
.09\end{array}$ & $\begin{array}{l}.00 \\
.05 \\
.06 \\
.04\end{array}$ \\
\hline $\begin{array}{r}\text { VS } \\
\text { MS } \\
\text { D } \\
\text { B }\end{array}$ & $\begin{array}{l}12.5 \\
12.5 \\
12.5 \\
12.5\end{array}$ & $\begin{array}{l}.00 \\
.06 \\
.08 \\
.11\end{array}$ & $\begin{array}{l}.00 \\
.03 \\
.07 \\
.03\end{array}$ & $\begin{array}{l}.00 \\
.00 \\
.00 \\
.00\end{array}$ & $\begin{array}{l}.00 \\
.00 \\
.00 \\
.00\end{array}$ & $\begin{array}{l}.00 \\
.00 \\
.00 \\
.00\end{array}$ & $\begin{array}{l}.00 \\
.00 \\
.00 \\
.00\end{array}$ & $\begin{array}{l}.00 \\
.01 \\
.01 \\
.00\end{array}$ & $\begin{array}{l}.00 \\
.02 \\
.00 \\
.00\end{array}$ & $\begin{array}{l}.00 \\
.10 \\
.04 \\
.01\end{array}$ & $\begin{array}{l}.01 \\
.33 \\
.11 \\
.07\end{array}$ & $\begin{array}{l}.01 \\
.19 \\
.06 \\
.01\end{array}$ & $\begin{array}{l}.00 \\
.20 \\
.32 \\
.12\end{array}$ & $\begin{array}{l}.00 \\
.45 \\
.48 \\
.40\end{array}$ & $\begin{array}{l}.00 \\
.12 \\
.14 \\
.05\end{array}$ & $\begin{array}{l}.00 \\
.01 \\
.01 \\
.01\end{array}$ & $\begin{array}{l}.00 \\
.06 \\
.02 \\
.01\end{array}$ \\
\hline
\end{tabular}


TABLE 5. Joint Frequency Data for Ground-Leve1 Releases, 200 Area

\begin{tabular}{|c|c|c|c|c|c|c|c|c|c|c|c|c|c|c|c|c|c|}
\hline $\begin{array}{c}\text { Stability } \\
\text { Class }\end{array}$ & \multirow{2}{*}{ 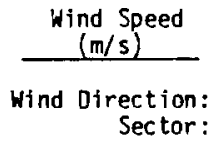 } & \multicolumn{16}{|c|}{ Percent of Time Wind is of Specified Direction, } \\
\hline & & $\begin{array}{l}\text { NNE } \\
\text { SSH } \\
\end{array}$ & $\begin{array}{l}\text { NE } \\
\text { SH }\end{array}$ & $\begin{array}{l}\text { ENE } \\
\text { WSW } \\
\end{array}$ & $\begin{array}{l}E \\
W \\
\end{array}$ & $\begin{array}{l}\text { ESE } \\
\text { WNH } \\
\end{array}$ & $\begin{array}{l}S E \\
\text { WW }\end{array}$ & $\begin{array}{l}\text { SSE } \\
\text { MNW } \\
\end{array}$ & $\begin{array}{l}\mathrm{S} \\
\mathrm{N} \\
\end{array}$ & $\begin{array}{l}\text { SSW } \\
\text { MNE } \\
\end{array}$ & $\begin{array}{l}\text { SH } \\
\text { ME } \\
\end{array}$ & $\begin{array}{l}\text { WSW } \\
\text { ENE } \\
\end{array}$ & $\begin{array}{l}H \\
E\end{array}$ & $\begin{array}{l}\text { HNH } \\
\text { ESE }\end{array}$ & $\begin{array}{l}\mathrm{NH} \\
\mathrm{SE} \\
\end{array}$ & $\begin{array}{l}\text { NNW } \\
\text { SSE } \\
\end{array}$ & $\begin{array}{l}N \\
S \\
\end{array}$ \\
\hline 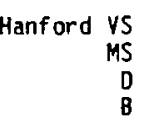 & $\begin{array}{l}0.78 \\
0.78 \\
0.78 \\
0.78\end{array}$ & $\begin{array}{l}.07 \\
.33 \\
.55 \\
.79\end{array}$ & $\begin{array}{l}.05 \\
.27 \\
.54 \\
.74\end{array}$ & $\begin{array}{l}.06 \\
.32 \\
.41 \\
.33\end{array}$ & $\begin{array}{l}.06 \\
.30 \\
.42 \\
.28\end{array}$ & $\begin{array}{l}.07 \\
.36 \\
.36 \\
.44\end{array}$ & $\begin{array}{l}.11 \\
.72 \\
.48 \\
.39\end{array}$ & $\begin{array}{l}.07 \\
.45 \\
.27 \\
.17\end{array}$ & $\begin{array}{l}.11 \\
.54 \\
.25 \\
.20\end{array}$ & $\begin{array}{l}.06 \\
.44 \\
.20 \\
.15\end{array}$ & $\begin{array}{l}.08 \\
.59 \\
.27 \\
.15\end{array}$ & $\begin{array}{l}.07 \\
.54 \\
.24 \\
.21\end{array}$ & $\begin{array}{l}.10 \\
.67 \\
.25 \\
.18\end{array}$ & $\begin{array}{l}.09 \\
.68 \\
.33 \\
.15\end{array}$ & $\begin{array}{l}.14 \\
.77 \\
.41 \\
.30\end{array}$ & $\begin{array}{l}.10 \\
.63 \\
.50 \\
.39\end{array}$ & $\begin{array}{l}.08 \\
.79 \\
.54 \\
.55\end{array}$ \\
\hline $\begin{array}{l}\text { VS } \\
\text { MS } \\
\text { D } \\
B\end{array}$ & $\begin{array}{l}2.5 \\
2.5 \\
2.5 \\
2.5\end{array}$ & $\begin{array}{r}.04 \\
.24 \\
.28 \\
1.12\end{array}$ & $\begin{array}{l}.03 \\
.26 \\
.21 \\
.78\end{array}$ & $\begin{array}{l}.01 \\
.20 \\
.16 \\
.53\end{array}$ & $\begin{array}{l}.02 \\
.26 \\
.20 \\
.54\end{array}$ & $\begin{array}{l}.02 \\
.44 \\
.34 \\
.60\end{array}$ & $\begin{array}{l}.14 \\
.68 \\
.28 \\
.66\end{array}$ & $\begin{array}{l}.15 \\
.62 \\
.17 \\
.34\end{array}$ & $\begin{array}{l}.10 \\
.63 \\
.20 \\
.35\end{array}$ & $\begin{array}{l}.17 \\
.56 \\
.21 \\
.50\end{array}$ & $\begin{array}{l}.18 \\
.90 \\
.25 \\
.52\end{array}$ & $\begin{array}{r}.26 \\
1.70 \\
.30 \\
.48\end{array}$ & $\begin{array}{r}.47 \\
2.48 \\
.45 \\
.43\end{array}$ & $\begin{array}{r}.44 \\
2.45 \\
.81 \\
.65\end{array}$ & $\begin{array}{r}.39 \\
2.29 \\
.96 \\
1.25\end{array}$ & $\begin{array}{r}.15 \\
.93 \\
.63 \\
1.33\end{array}$ & $\begin{array}{r}.04 \\
.36 \\
.39 \\
1.16\end{array}$ \\
\hline $\begin{array}{l}\text { VS } \\
\text { MS } \\
\text { D } \\
\text { B }\end{array}$ & $\begin{array}{l}4.5 \\
4.5 \\
4.5 \\
4.5\end{array}$ & $\begin{array}{l}.00 \\
.07 \\
.16 \\
.46\end{array}$ & $\begin{array}{l}.00 \\
.02 \\
.05 \\
.18\end{array}$ & $\begin{array}{l}.00 \\
.03 \\
.03 \\
.08\end{array}$ & $\begin{array}{l}.00 \\
.06 \\
.04 \\
.09\end{array}$ & $\begin{array}{l}.00 \\
.11 \\
.08 \\
.06\end{array}$ & $\begin{array}{l}.02 \\
.21 \\
.10 \\
.08\end{array}$ & $\begin{array}{l}.03 \\
.39 \\
.11 \\
.08\end{array}$ & $\begin{array}{l}.01 \\
.25 \\
.09 \\
.08\end{array}$ & $\begin{array}{l}.02 \\
.28 \\
.27 \\
.27\end{array}$ & $\begin{array}{l}.05 \\
.62 \\
.32 \\
.50\end{array}$ & $\begin{array}{r}.39 \\
1.74 \\
.53 \\
.76\end{array}$ & $\begin{array}{r}.21 \\
2.48 \\
.65 \\
.30\end{array}$ & $\begin{array}{r}.78 \\
4.06 \\
1.23 \\
.75\end{array}$ & $\begin{array}{l}.43 \\
2.50 \\
1.02 \\
1.33\end{array}$ & $\begin{array}{l}.01 \\
.46 \\
.32 \\
.42\end{array}$ & $\begin{array}{l}.00 \\
.11 \\
.14 \\
.34\end{array}$ \\
\hline $\begin{array}{l}\text { VS } \\
\text { MS } \\
D \\
B\end{array}$ & $\begin{array}{l}6.9 \\
6.9 \\
6.9 \\
6.9\end{array}$ & $\begin{array}{l}.00 \\
.01 \\
.04 \\
.16\end{array}$ & $\begin{array}{l}.00 \\
.01 \\
.05 \\
.06\end{array}$ & $\begin{array}{l}.00 \\
.00 \\
.01 \\
.00\end{array}$ & $\begin{array}{l}.00 \\
.00 \\
.00 \\
.00\end{array}$ & $\begin{array}{l}.00 \\
.00 \\
.01 \\
.00\end{array}$ & $\begin{array}{l}.00 \\
.03 \\
.01 \\
.00\end{array}$ & $\begin{array}{l}.00 \\
.04 \\
.04 \\
.03\end{array}$ & $\begin{array}{l}.00 \\
.11 \\
.08 \\
.02\end{array}$ & $\begin{array}{l}.00 \\
.17 \\
.30 \\
.15\end{array}$ & $\begin{array}{l}.00 \\
.43 \\
.60 \\
.48\end{array}$ & $\begin{array}{l}.01 \\
.65 \\
.52 \\
.67\end{array}$ & $\begin{array}{l}.00 \\
.34 \\
.38 \\
.25\end{array}$ & $\begin{array}{r}.01 \\
1.42 \\
1.33 \\
.64\end{array}$ & $\begin{array}{l}.00 \\
.93 \\
.86 \\
.80\end{array}$ & $\begin{array}{l}.00 \\
.04 \\
.09 \\
.07\end{array}$ & $\begin{array}{l}.0 \\
.0 \\
.0\end{array}$ \\
\hline $\begin{array}{l}\text { VS } \\
\text { MS } \\
\text { D } \\
\text { B }\end{array}$ & $\begin{array}{l}9.5 \\
9.5 \\
9.5 \\
9.5\end{array}$ & $\begin{array}{l}.00 \\
.00 \\
.01 \\
.01\end{array}$ & $\begin{array}{l}.00 \\
.02 \\
.02 \\
.00\end{array}$ & $\begin{array}{l}.00 \\
.00 \\
.00 \\
.00\end{array}$ & $\begin{array}{l}.00 \\
.00 \\
.00 \\
.00\end{array}$ & $\begin{array}{l}.00 \\
.00 \\
.00 \\
.00\end{array}$ & $\begin{array}{l}.00 \\
.01 \\
.00 \\
.00\end{array}$ & $\begin{array}{l}.00 \\
.03 \\
.00 \\
.00\end{array}$ & $\begin{array}{l}.00 \\
.04 \\
.05 \\
.00\end{array}$ & $\begin{array}{l}.00 \\
.11 \\
.17 \\
.06\end{array}$ & $\begin{array}{l}.00 \\
.19 \\
.35 \\
.32\end{array}$ & $\begin{array}{l}.00 \\
.09 \\
.17 \\
.29\end{array}$ & $\begin{array}{l}.00 \\
.02 \\
.05 \\
.05\end{array}$ & $\begin{array}{l}.00 \\
.25 \\
.62 \\
.32\end{array}$ & $\begin{array}{l}.00 \\
.14 \\
.65 \\
.57\end{array}$ & $\begin{array}{l}.00 \\
.00 \\
.02 \\
.01\end{array}$ & $\begin{array}{l}.00 \\
.01 \\
.01 \\
.03\end{array}$ \\
\hline $\begin{array}{r}\text { VS } \\
M S \\
D \\
B\end{array}$ & $\begin{array}{l}12.5 \\
12.5 \\
12.5 \\
12.5\end{array}$ & $\begin{array}{l}.00 \\
.00 \\
.00 \\
.00\end{array}$ & $\begin{array}{l}.00 \\
.00 \\
.00 \\
.00\end{array}$ & $\begin{array}{l}.00 \\
.00 \\
.00 \\
.00\end{array}$ & $\begin{array}{l}.00 \\
.00 \\
.00 \\
.00\end{array}$ & $\begin{array}{l}.00 \\
.00 \\
.00 \\
.00\end{array}$ & $\begin{array}{l}.00 \\
.00 \\
.00 \\
.00\end{array}$ & $\begin{array}{l}.00 \\
.01 \\
.00 \\
.00\end{array}$ & $\begin{array}{l}.00 \\
.00 \\
.01 \\
.00\end{array}$ & $\begin{array}{l}.00 \\
.06 \\
.11 \\
.02\end{array}$ & $\begin{array}{l}.00 \\
.09 \\
.13 \\
.17\end{array}$ & $\begin{array}{l}.00 \\
.02 \\
.06 \\
.08\end{array}$ & $\begin{array}{l}.00 \\
.00 \\
.01 \\
.01\end{array}$ & $\begin{array}{l}.00 \\
.02 \\
.08 \\
.11\end{array}$ & $\begin{array}{l}.00 \\
.00 \\
.11 \\
.21\end{array}$ & $\begin{array}{l}.00 \\
.00 \\
.00 \\
.01\end{array}$ & $\begin{array}{l}.00 \\
.00 \\
.00 \\
.00\end{array}$ \\
\hline
\end{tabular}

TABLE 6. Joint Frequency Data for Elevated Releases, 200 Area

\begin{tabular}{|c|c|c|c|c|c|c|c|c|c|c|c|c|c|c|c|c|c|}
\hline $\begin{array}{c}\text { Stability } \\
\text { Class }\end{array}$ & $\begin{array}{l}\text { Wind Speed } \\
(\mathrm{m} / \mathrm{s})\end{array}$ & & & & rce & of & ime & ind $i$ & of $S$ & ecifis & Dir & tion, & Speed, & and Sta & 11 ity & & \\
\hline & $\begin{array}{l}\text { Wind Direction: } \\
\text { Sector: }\end{array}$ & $\begin{array}{l}\text { NNE } \\
\text { SSH } \\
\end{array}$ & $\begin{array}{l}\text { NE } \\
\text { SW }\end{array}$ & $\begin{array}{l}\text { ENE } \\
\text { WSH } \\
\end{array}$ & $\begin{array}{l}E \\
W \\
\end{array}$ & $\begin{array}{l}\text { ESE } \\
\text { WNH } \\
\end{array}$ & $\begin{array}{l}\text { SE } \\
\text { NH } \\
\end{array}$ & $\begin{array}{l}\text { SSE } \\
\text { HNN }\end{array}$ & $\begin{array}{l}S \\
N \\
\end{array}$ & $\begin{array}{l}\text { SSW } \\
\text { MNE }\end{array}$ & $\begin{array}{l}\text { SH } \\
\text { NE }\end{array}$ & $\begin{array}{l}\text { WSH } \\
\text { ENE } \\
\end{array}$ & $\begin{array}{l}H \\
E\end{array}$ & $\begin{array}{l}\text { HNH } \\
\text { ESE }\end{array}$ & $\begin{array}{l}\text { NW } \\
\text { SE } \\
\end{array}$ & $\begin{array}{l}\text { NMH } \\
\text { SSE } \\
\end{array}$ & $\begin{array}{l}N \\
S \\
\end{array}$ \\
\hline $\begin{array}{r}\text { Hanford VS } \\
\text { MS } \\
D \\
B\end{array}$ & $\begin{array}{l}0.78 \\
0.78 \\
0.78 \\
0.78\end{array}$ & $\begin{array}{l}.24 \\
.20 \\
.34 \\
.54\end{array}$ & $\begin{array}{l}.24 \\
.21 \\
.39 \\
.71\end{array}$ & $\begin{array}{l}.17 \\
.19 \\
.31 \\
.40\end{array}$ & $\begin{array}{l}.23 \\
.25 \\
.38 \\
.44\end{array}$ & $\begin{array}{l}.30 \\
.39 \\
.41 \\
.34\end{array}$ & $\begin{array}{l}.44 \\
.50 \\
.50 \\
.30\end{array}$ & $\begin{array}{l}.26 \\
.24 \\
.25 \\
.13\end{array}$ & $\begin{array}{l}.26 \\
.21 \\
.17 \\
.19\end{array}$ & $\begin{array}{l}.23 \\
.14 \\
.15 \\
.11\end{array}$ & $\begin{array}{l}.26 \\
.14 \\
.13 \\
.18\end{array}$ & $\begin{array}{l}.25 \\
.15 \\
.11 \\
.11\end{array}$ & $\begin{array}{l}.46 \\
.25 \\
.21 \\
.16\end{array}$ & $\begin{array}{l}.39 \\
.26 \\
.21 \\
.16\end{array}$ & $\begin{array}{l}.50 \\
.37 \\
.38 \\
.30\end{array}$ & $\begin{array}{l}.43 \\
.33 \\
.47 \\
.41\end{array}$ & $\begin{array}{l}.40 \\
.34 \\
.47 \\
.60\end{array}$ \\
\hline $\begin{array}{r}V S \\
M S \\
D \\
B\end{array}$ & $\begin{array}{l}2.5 \\
2.5 \\
2.5 \\
2.5\end{array}$ & $\begin{array}{l}.21 \\
.17 \\
.12 \\
.97\end{array}$ & $\begin{array}{l}.18 \\
.15 \\
.13 \\
.93\end{array}$ & $\begin{array}{l}.14 \\
.13 \\
.10 \\
.57\end{array}$ & $\begin{array}{l}.17 \\
.15 \\
.12 \\
.60\end{array}$ & $\begin{array}{l}.20 \\
.22 \\
.19 \\
.55\end{array}$ & $\begin{array}{l}.33 \\
.36 \\
.26 \\
.64\end{array}$ & $\begin{array}{l}.28 \\
.21 \\
.14 \\
.38\end{array}$ & $\begin{array}{l}.28 \\
.17 \\
.10 \\
.46\end{array}$ & $\begin{array}{l}.24 \\
.15 \\
.07 \\
.46\end{array}$ & $\begin{array}{l}.35 \\
.21 \\
.10 \\
.52\end{array}$ & $\begin{array}{l}.50 \\
.24 \\
.11 \\
.38\end{array}$ & $\begin{array}{l}.96 \\
.42 \\
.16 \\
.39\end{array}$ & $\begin{array}{r}1.08 \\
.50 \\
.27 \\
.49\end{array}$ & $\begin{array}{r}1.00 \\
.68 \\
.55 \\
1.16\end{array}$ & $\begin{array}{r}.69 \\
.47 \\
.33 \\
1.14\end{array}$ & $\begin{array}{l}.39 \\
.31 \\
.18 \\
1.21\end{array}$ \\
\hline $\begin{array}{r}V S \\
\text { MS } \\
0 \\
B\end{array}$ & $\begin{array}{l}4.5 \\
4.5 \\
4.5 \\
4.5\end{array}$ & $\begin{array}{l}.13 \\
.11 \\
.06 \\
.48\end{array}$ & $\begin{array}{l}.11 \\
.08 \\
.04 \\
.33\end{array}$ & $\begin{array}{l}.08 \\
.03 \\
.03 \\
.12\end{array}$ & $\begin{array}{l}.07 \\
.06 \\
.03 \\
.09\end{array}$ & $\begin{array}{l}.07 \\
.10 \\
.04 \\
.09\end{array}$ & $\begin{array}{l}.13 \\
.21 \\
.09 \\
.15\end{array}$ & $\begin{array}{l}.21 \\
.19 \\
.07 \\
.11\end{array}$ & $\begin{array}{l}.11 \\
.13 \\
.04 \\
.14\end{array}$ & $\begin{array}{l}.12 \\
.20 \\
.06 \\
.34\end{array}$ & $\begin{array}{l}.24 \\
.34 \\
.09 \\
.59\end{array}$ & $\begin{array}{l}.59 \\
.50 \\
.14 \\
.56\end{array}$ & $\begin{array}{r}1.23 \\
.96 \\
.14 \\
.33\end{array}$ & $\begin{array}{r}2.00 \\
1.47 \\
.42 \\
.59\end{array}$ & $\begin{array}{r}1.74 \\
1.53 \\
.78 \\
1.42\end{array}$ & $\begin{array}{l}.60 \\
.38 \\
.15 \\
.52\end{array}$ & $\begin{array}{l}.20 \\
.14 \\
.06 \\
.45\end{array}$ \\
\hline $\begin{array}{r}\text { VS } \\
\text { MS } \\
\text { D } \\
B\end{array}$ & $\begin{array}{l}6.9 \\
6.9 \\
6.9 \\
6.9\end{array}$ & $\begin{array}{l}.05 \\
.10 \\
.05 \\
.26\end{array}$ & $\begin{array}{l}.03 \\
.05 \\
.01 \\
.13\end{array}$ & $\begin{array}{l}.02 \\
.02 \\
.01 \\
.03\end{array}$ & $\begin{array}{l}.02 \\
.02 \\
.01 \\
.01\end{array}$ & $\begin{array}{l}.00 \\
.02 \\
.00 \\
.01\end{array}$ & $\begin{array}{l}.04 \\
.07 \\
.03 \\
.03\end{array}$ & $\begin{array}{l}.10 \\
.13 \\
.04 \\
.04\end{array}$ & $\begin{array}{l}.03 \\
.15 \\
.05 \\
.05\end{array}$ & $\begin{array}{l}.03 \\
.25 \\
.07 \\
.18\end{array}$ & $\begin{array}{l}.09 \\
.54 \\
.14 \\
.54\end{array}$ & $\begin{array}{l}.25 \\
.87 \\
.24 \\
.68\end{array}$ & $\begin{array}{r}.43 \\
1.24 \\
.16 \\
.26\end{array}$ & $\begin{array}{r}1.25 \\
3.04 \\
.44 \\
.64\end{array}$ & $\begin{array}{r}1.53 \\
2.23 \\
.58 \\
.98\end{array}$ & $\begin{array}{l}.17 \\
.18 \\
.06 \\
.09\end{array}$ & $\begin{array}{l}.05 \\
.10 \\
.04 \\
.14\end{array}$ \\
\hline $\begin{array}{r}\text { VS } \\
\text { MS } \\
D \\
B\end{array}$ & $\begin{array}{l}9.5 \\
9.5 \\
9.5 \\
9.5\end{array}$ & $\begin{array}{l}.00 \\
.04 \\
.02 \\
.06\end{array}$ & $\begin{array}{l}.00 \\
.03 \\
.02 \\
.05\end{array}$ & $\begin{array}{l}.00 \\
.01 \\
.00 \\
.01\end{array}$ & $\begin{array}{l}.00 \\
.00 \\
.00 \\
.00\end{array}$ & $\begin{array}{l}.00 \\
.00 \\
.00 \\
.00\end{array}$ & $\begin{array}{l}.00 \\
.02 \\
.01 \\
.00\end{array}$ & $\begin{array}{l}.01 \\
.06 \\
.01 \\
.01\end{array}$ & $\begin{array}{l}.01 \\
.11 \\
.03 \\
.02\end{array}$ & $\begin{array}{l}.01 \\
.21 \\
.08 \\
.11\end{array}$ & $\begin{array}{l}.02 \\
.53 \\
.15 \\
.34\end{array}$ & $\begin{array}{l}.04 \\
.50 \\
.17 \\
.41\end{array}$ & $\begin{array}{l}.02 \\
.33 \\
.05 \\
.12\end{array}$ & $\begin{array}{r}.06 \\
1.55 \\
.25 \\
.32\end{array}$ & $\begin{array}{r}.18 \\
1.45 \\
.34 \\
.63\end{array}$ & $\begin{array}{l}.00 \\
.03 \\
.01 \\
.01\end{array}$ & $\begin{array}{l}.00 \\
.02 \\
.02 \\
.03\end{array}$ \\
\hline $\begin{array}{r}\text { VS } \\
\text { MS } \\
0 \\
B\end{array}$ & $\begin{array}{l}12.5 \\
12.5 \\
12.5 \\
12.5\end{array}$ & $\begin{array}{l}.00 \\
.01 \\
.01 \\
.02\end{array}$ & $\begin{array}{l}.00 \\
.01 \\
.01 \\
.03\end{array}$ & $\begin{array}{l}.00 \\
.00 \\
.00 \\
.01\end{array}$ & $\begin{array}{l}.00 \\
.00 \\
.00 \\
.00\end{array}$ & $\begin{array}{l}.00 \\
.00 \\
.00 \\
.00\end{array}$ & $\begin{array}{l}.00 \\
.01 \\
.00 \\
.00\end{array}$ & $\begin{array}{l}.00 \\
.02 \\
.01 \\
.00\end{array}$ & $\begin{array}{l}.00 \\
.08 \\
.02 \\
.01\end{array}$ & $\begin{array}{l}.01 \\
.30 \\
.08 \\
.09\end{array}$ & $\begin{array}{l}.01 \\
.47 \\
.17 \\
.40\end{array}$ & $\begin{array}{l}.00 \\
.22 \\
.09 \\
.31\end{array}$ & $\begin{array}{l}.00 \\
.06 \\
.03 \\
.08\end{array}$ & $\begin{array}{l}.00 \\
.55 \\
.21 \\
.17\end{array}$ & $\begin{array}{l}.00 \\
.76 \\
.30 \\
.46\end{array}$ & $\begin{array}{l}.00 \\
.00 \\
.00 \\
.01\end{array}$ & $\begin{array}{l}.00 \\
.01 \\
.01 \\
.00\end{array}$ \\
\hline
\end{tabular}


the Hanford Annual Report for the $61 \mathrm{~m}$ release weight. Population distributions around the Hanford meteorlogical tower are available in the Hanford Annual Report and in Yandon and Landstrom, 1980. These values are also available in PNL-3777.

Because the 200 Areas are located a significant distance from the nearest residence, a special set of assumptions is normally used to determine the location of the maximally-exposed individual for accidental releases. For purposes of inhalation and submersion calculations, the maximum individual is assumed to be traveling on Highway $240,8.8 \mathrm{~km}$ ( $5.5 \mathrm{miles}$ ) southwest of the 200 Areas, but for ingestion dose calculations, he is assumed to farm $24 \mathrm{~km}$ (15.5 miles) down wind in the east-southeast direction. This is currently the approximate location of the nearest farm at Ringold. For chronic releases, the maximumally exposed individual is assumed to live continuously on the farm at Ringold for all pathway calculations.

For acute ground-level releases, the $E / Q$ at the Hanford Highway 240 is $3.0 \times 10^{-5} \mathrm{sec} / \mathrm{m}^{3}$, and at Ringold it is $7.6 \times 10^{-6} \mathrm{sec} / \mathrm{m}^{3}$. For acute elevated releases the $E / Q$ is $1.6 \times 10^{-5}$ and $6.1 \times 10^{-6} \mathrm{sec} / \mathrm{m}^{3}$ at the highway and Ringold, respectively. The $\bar{x} / Q^{\prime}$ values at Ringold from chronic releases are $7.4 \times 10^{-8} \mathrm{sec} / \mathrm{m}^{3}$ for ground-level and $4.5 \times 10^{-9} \mathrm{sec} / \mathrm{m}^{3}$ for elevated releases.

\section{Area}

Dispersion parameters for the 300 Area are based on meteorological data collected by the Washington Public Power Supply System (WPPSS) for the period April 1974 through March 1976. Strictly interpreted, these data, presented in Table 7, are actually for the WPPSS tower 7 miles northwest of the 300 Area. Because of its proximity and similar surrounding topography, the WPPSS No. 2 tower data are considered to be generally representative of the conditions as they might be measured in the 300 Area. Population distributions around the 300 Area are available from the Hanford Annual Report from Stein and Yandon, 1980, or from PNL-3777. 
TABLE 7. Joint Frequency Data for Ground-Level Releases, 300 Area

\begin{tabular}{|c|c|c|c|c|c|c|c|c|c|c|c|c|c|c|c|c|c|c|}
\hline \multicolumn{2}{|c|}{$\begin{array}{c}\text { Stability } \\
\text { Class } \\
\end{array}$} & \multirow{2}{*}{ 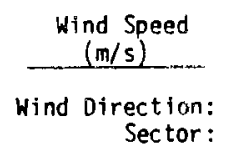 } & \multicolumn{16}{|c|}{ Percent of Time Wind is of Specified Direction, } \\
\hline & & & $\begin{array}{l}\text { MNE } \\
\text { SSW } \\
\end{array}$ & $\begin{array}{l}\text { NE } \\
\text { SW } \\
\end{array}$ & $\begin{array}{l}\text { ENE } \\
\text { WSW } \\
\end{array}$ & $\begin{array}{l}E \\
W \\
\end{array}$ & $\begin{array}{l}\text { ESE } \\
\text { WNH }\end{array}$ & $\begin{array}{l}\text { SE } \\
\text { MH }\end{array}$ & $\begin{array}{l}\text { SSE } \\
\text { NNW }\end{array}$ & $\begin{array}{l}\mathrm{S} \\
\mathrm{N}\end{array}$ & $\begin{array}{l}\text { SSW } \\
\text { NNE }\end{array}$ & $\begin{array}{l}\text { SW } \\
\text { NE } \\
\end{array}$ & $\begin{array}{l}\text { WSW } \\
\text { ENE }\end{array}$ & $\begin{array}{l}W \\
E\end{array}$ & $\begin{array}{l}\text { WNH } \\
\text { ESE }\end{array}$ & $\begin{array}{l}\mathrm{NW} \\
\mathrm{SE} \\
\end{array}$ & $\begin{array}{l}\text { NNH } \\
\text { SSE }\end{array}$ & $\begin{array}{r}N \\
S \\
\end{array}$ \\
\hline Pasquill & $\begin{array}{l}A \\
B \\
C \\
D \\
E \\
F\end{array}$ & $\begin{array}{l}0.78 \\
0.78 \\
0.78 \\
0.78 \\
0.78 \\
0.78\end{array}$ & $\begin{array}{l}.01 \\
.01 \\
.05 \\
.22 \\
.25 \\
.89\end{array}$ & $\begin{array}{l}.00 \\
.00 \\
.03 \\
.17 \\
.19 \\
.80\end{array}$ & $\begin{array}{l}.00 \\
.01 \\
.01 \\
.18 \\
.15 \\
.61\end{array}$ & $\begin{array}{l}.00 \\
.01 \\
.02 \\
.19 \\
.19 \\
.60\end{array}$ & $\begin{array}{l}.00 \\
.00 \\
.03 \\
.32 \\
.26 \\
.53\end{array}$ & $\begin{array}{l}.01 \\
.01 \\
.01 \\
.31 \\
.31 \\
.43\end{array}$ & $\begin{array}{l}.00 \\
.00 \\
.01 \\
.34 \\
.28 \\
.43\end{array}$ & $\begin{array}{l}.00 \\
.01 \\
.03 \\
.23 \\
.38 \\
.48\end{array}$ & $\begin{array}{l}.00 \\
.02 \\
.01 \\
.32 \\
.27 \\
.54\end{array}$ & $\begin{array}{l}.00 \\
.01 \\
.02 \\
.34 \\
.28 \\
.49\end{array}$ & $\begin{array}{l}.00 \\
.01 \\
.03 \\
.24 \\
.32 \\
.52\end{array}$ & $\begin{array}{l}.00 \\
.01 \\
.02 \\
.23 \\
.28 \\
.42\end{array}$ & $\begin{array}{l}.00 \\
.01 \\
.03 \\
.40 \\
.49 \\
.69\end{array}$ & $\begin{array}{l}.01 \\
.01 \\
.06 \\
.42 \\
.47 \\
.83\end{array}$ & $\begin{array}{l}.01 \\
.01 \\
.07 \\
.47 \\
.42 \\
1.06\end{array}$ & $\begin{array}{r}.01 \\
.01 \\
.05 \\
.35 \\
.37 \\
1.02\end{array}$ \\
\hline Pasquili & $\begin{array}{l}\text { A } \\
\text { B } \\
\text { C } \\
\text { D } \\
\text { E } \\
\text { F }\end{array}$ & $\begin{array}{l}2.5 \\
2.5 \\
2.5 \\
2.5 \\
2.5 \\
2.5\end{array}$ & $\begin{array}{l}.09 \\
.11 \\
.27 \\
.52 \\
.18 \\
.75\end{array}$ & $\begin{array}{l}.04 \\
.08 \\
.14 \\
.24 \\
.29 \\
.71\end{array}$ & $\begin{array}{l}.04 \\
.03 \\
.11 \\
.35 \\
.27 \\
.43\end{array}$ & $\begin{array}{l}.03 \\
.03 \\
.05 \\
.30 \\
.19 \\
.14\end{array}$ & $\begin{array}{l}.02 \\
.09 \\
.13 \\
.30 \\
.19 \\
.23\end{array}$ & $\begin{array}{l}.09 \\
.10 \\
.23 \\
.67 \\
.45 \\
.69\end{array}$ & $\begin{array}{l}.07 \\
.13 \\
.42 \\
.92 \\
.89 \\
1.62\end{array}$ & $\begin{array}{r}.04 \\
.08 \\
.38 \\
.82 \\
.79 \\
1.55\end{array}$ & $\begin{array}{l}.05 \\
.11 \\
.24 \\
.65 \\
.59 \\
.99\end{array}$ & $\begin{array}{l}.07 \\
.11 \\
.21 \\
.36 \\
.57 \\
.55\end{array}$ & $\begin{array}{l}.02 \\
.07 \\
.16 \\
.33 \\
.53 \\
.45\end{array}$ & $\begin{array}{l}.06 \\
.15 \\
.17 \\
.35 \\
.55 \\
.45\end{array}$ & $\begin{array}{l}.05 \\
.09 \\
.17 \\
.55 \\
.93 \\
.74\end{array}$ & $\begin{array}{r}.07 \\
.11 \\
.23 \\
.96 \\
1.26 \\
1.48\end{array}$ & $\begin{array}{r}.13 \\
.22 \\
.32 \\
.89 \\
.83 \\
1.40\end{array}$ & $\begin{array}{l}.13 \\
.19 \\
.42 \\
.54 \\
.39 \\
.87\end{array}$ \\
\hline Pasquill & $\begin{array}{l}A \\
B \\
C \\
D \\
E \\
F\end{array}$ & $\begin{array}{l}4.5 \\
4.5 \\
4.5 \\
4.5 \\
4.5 \\
4.5\end{array}$ & $\begin{array}{l}.10 \\
.08 \\
.21 \\
.25 \\
.07 \\
.06\end{array}$ & $\begin{array}{l}.06 \\
.03 \\
.08 \\
.11 \\
.04 \\
.05\end{array}$ & $\begin{array}{l}.05 \\
.00 \\
.10 \\
.12 \\
.05 \\
.09\end{array}$ & $\begin{array}{l}.01 \\
.02 \\
.06 \\
.06 \\
.02 \\
.01\end{array}$ & $\begin{array}{l}.02 \\
.05 \\
.05 \\
.05 \\
.05 \\
.00\end{array}$ & $\begin{array}{l}.04 \\
.04 \\
.08 \\
.15 \\
.25 \\
.12\end{array}$ & $\begin{array}{l}.06 \\
.08 \\
.18 \\
.39 \\
.85 \\
.80\end{array}$ & $\begin{array}{l}.27 \\
.31 \\
.58 \\
.89 \\
.79 \\
.96\end{array}$ & $\begin{array}{r}.05 \\
.10 \\
.34 \\
1.01 \\
.56 \\
.48\end{array}$ & $\begin{array}{l}.03 \\
.06 \\
.14 \\
.40 \\
.37 \\
.15\end{array}$ & $\begin{array}{l}.03 \\
.06 \\
.15 \\
.26 \\
.40 \\
.15\end{array}$ & $\begin{array}{l}.06 \\
.05 \\
.16 \\
.28 \\
.46 \\
.27\end{array}$ & $\begin{array}{r}.05 \\
.02 \\
.09 \\
.49 \\
1.19 \\
.52\end{array}$ & $\begin{array}{r}.10 \\
.06 \\
.09 \\
.64 \\
1.24 \\
.54\end{array}$ & $\begin{array}{l}.11 \\
.07 \\
.13 \\
.46 \\
.47 \\
.15\end{array}$ & $\begin{array}{l}.11 \\
.09 \\
.28 \\
.37 \\
.13 \\
.07\end{array}$ \\
\hline Pasquil1 & $\begin{array}{l}A \\
B \\
C \\
D \\
E \\
F\end{array}$ & $\begin{array}{l}6.9 \\
6.9 \\
6.9 \\
6.9 \\
6.9 \\
6.9\end{array}$ & $\begin{array}{l}.03 \\
.02 \\
.05 \\
.07 \\
.02 \\
.00\end{array}$ & $\begin{array}{l}.01 \\
.00 \\
.01 \\
.02 \\
.01 \\
.02\end{array}$ & $\begin{array}{l}.00 \\
.00 \\
.00 \\
.00 \\
.01 \\
.00\end{array}$ & $\begin{array}{l}.00 \\
.00 \\
.00 \\
.00 \\
.00 \\
.00\end{array}$ & $\begin{array}{l}.00 \\
.00 \\
.00 \\
.00 \\
.00 \\
.00\end{array}$ & $\begin{array}{l}.01 \\
.00 \\
.02 \\
.05 \\
.05 \\
.00\end{array}$ & $\begin{array}{l}.02 \\
.01 \\
.01 \\
.10 \\
.17 \\
.03\end{array}$ & $\begin{array}{l}.12 \\
.07 \\
.07 \\
.38 \\
.40 \\
.14\end{array}$ & $\begin{array}{l}.10 \\
.11 \\
.24 \\
.83 \\
.73 \\
.14\end{array}$ & $\begin{array}{l}.05 \\
.03 \\
.21 \\
.58 \\
.44 \\
.03\end{array}$ & $\begin{array}{l}.05 \\
.06 \\
.14 \\
.26 \\
.14 \\
.00\end{array}$ & $\begin{array}{l}.05 \\
.05 \\
.11 \\
.27 \\
.15 \\
.01\end{array}$ & $\begin{array}{l}.05 \\
.06 \\
.06 \\
.47 \\
.75 \\
.01\end{array}$ & $\begin{array}{l}.08 \\
.05 \\
.08 \\
.54 \\
.42 \\
.03\end{array}$ & $\begin{array}{l}.03 \\
.03 \\
.07 \\
.13 \\
.07 \\
.00\end{array}$ & $\begin{array}{l}.04 \\
.06 \\
.09 \\
.13 \\
.01 \\
.00\end{array}$ \\
\hline Pasquill & $\begin{array}{l}A \\
B \\
C \\
D \\
E \\
F\end{array}$ & $\begin{array}{l}9.5 \\
9.5 \\
9.5 \\
9.5 \\
9.5 \\
9.5\end{array}$ & $\begin{array}{l}.00 \\
.00 \\
.00 \\
.01 \\
.04 \\
.00\end{array}$ & $\begin{array}{l}.00 \\
.00 \\
.00 \\
.01 \\
.00 \\
.00\end{array}$ & $\begin{array}{l}.00 \\
.00 \\
.00 \\
.00 \\
.00 \\
.00\end{array}$ & $\begin{array}{l}.00 \\
.00 \\
.00 \\
.00 \\
.00 \\
.00\end{array}$ & $\begin{array}{l}.00 \\
.00 \\
.00 \\
.00 \\
.00 \\
.00\end{array}$ & $\begin{array}{l}.00 \\
.00 \\
.00 \\
.01 \\
.01 \\
.00\end{array}$ & $\begin{array}{l}.00 \\
.00 \\
.00 \\
.00 \\
.02 \\
.00\end{array}$ & $\begin{array}{l}.03 \\
.01 \\
.02 \\
.05 \\
.03 \\
.00\end{array}$ & $\begin{array}{l}.00 \\
.02 \\
.05 \\
.23 \\
.32 \\
.00\end{array}$ & $\begin{array}{l}.03 \\
.03 \\
.07 \\
.29 \\
.17 \\
.00\end{array}$ & $\begin{array}{l}.03 \\
.04 \\
.07 \\
.13 \\
.07 \\
.00\end{array}$ & $\begin{array}{l}.07 \\
.03 \\
.06 \\
.09 \\
.05 \\
.00\end{array}$ & $\begin{array}{l}.05 \\
.03 \\
.03 \\
.34 \\
.17 \\
.00\end{array}$ & $\begin{array}{l}.10 \\
.05 \\
.07 \\
.31 \\
.06 \\
.01\end{array}$ & $\begin{array}{l}.01 \\
.00 \\
.02 \\
.02 \\
.00 \\
.00\end{array}$ & $\begin{array}{l}.00 \\
.00 \\
.01 \\
.00 \\
.00 \\
.00\end{array}$ \\
\hline Pasquill & $\begin{array}{l}A \\
B \\
C \\
D \\
E \\
F\end{array}$ & $\begin{array}{l}12.5 \\
12.5 \\
12.5 \\
12.5 \\
12.5 \\
12.5\end{array}$ & $\begin{array}{l}.00 \\
.00 \\
.00 \\
.07 \\
.05 \\
.00\end{array}$ & $\begin{array}{l}.00 \\
.00 \\
.00 \\
.00 \\
.00 \\
.00\end{array}$ & $\begin{array}{l}.00 \\
.00 \\
.00 \\
.00 \\
.00 \\
.00\end{array}$ & $\begin{array}{l}.00 \\
.00 \\
.00 \\
.00 \\
.00 \\
.00\end{array}$ & $\begin{array}{l}.00 \\
.00 \\
.00 \\
.00 \\
.00 \\
.00\end{array}$ & $\begin{array}{l}.00 \\
.00 \\
.00 \\
.00 \\
.00 \\
.00\end{array}$ & $\begin{array}{l}.00 \\
.00 \\
.00 \\
.00 \\
.00 \\
.00\end{array}$ & $\begin{array}{l}.00 \\
.00 \\
.00 \\
.00 \\
.00 \\
.00\end{array}$ & $\begin{array}{l}.00 \\
.00 \\
.00 \\
.11 \\
.11 \\
.00\end{array}$ & $\begin{array}{l}.01 \\
.01 \\
.03 \\
.15 \\
.06 \\
.00\end{array}$ & $\begin{array}{l}.03 \\
.01 \\
.02 \\
.05 \\
.03 \\
.00\end{array}$ & $\begin{array}{l}.03 \\
.01 \\
.03 \\
.05 \\
.01 \\
.00\end{array}$ & $\begin{array}{l}.02 \\
.02 \\
.01 \\
.06 \\
.03 \\
.00\end{array}$ & $\begin{array}{l}.05 \\
.03 \\
.05 \\
.13 \\
.00 \\
.00\end{array}$ & $\begin{array}{l}.01 \\
.00 \\
.00 \\
.00 \\
.00 \\
.00\end{array}$ & $\begin{array}{l}.01 \\
.00 \\
.00 \\
.00 \\
.00 \\
.00\end{array}$ \\
\hline
\end{tabular}


The maximum individual is defined to live $2.4 \mathrm{~km}$ ( $1.5 \mathrm{miles}$ ) east of the 300 Area. This area directly across the Columbia River is the current location of the nearest dairy and farming activity.

The WPPSS joint frequency data are for the 11 meter elevation. This is essentially ground level. Most atmospheric releases from the 300 Area are from roof vents, or short stacks barely above roof level, so only ground level $\bar{X} / Q$ ' values are calculated. The $E / Q$ from an acute release at the location of the maximum individual is $1.9 \times 10^{-4} \mathrm{sec} / \mathrm{m}^{3}$. For a chronic release $\bar{X} / Q^{\prime}$ is $1.1 \times 10^{-6} \mathrm{sec} / \mathrm{m}^{3}$.

\subsection{Exposure Parameters}

Data required to run many of the dose programs include dietary and recreational preferences and habits in the general population, as well as agricultural practices in the general region. Surveys of these items have been performed for the Hanford environs (Bustad and Terry 1956, Essig and Corley 1969). Results of these surveys have been summarized and used in environmental studies of Hanford (ERDA 1975, Houston and Blumer 1979). These parameters undergo periodic review and updating by the Hanford Dose Overview Program.

The standard Hanford terrestrial pathway data are presented in Table 8. The columns for exposure pathway, growing period, yield, and irrigation rate reflect the agricultural practices prevalent in the south central Washington Columbia River Basin. The average holdup time between harvest and consumption and the average consumption rates reflect the dietary habits of the Tri-Cities residents. The values for maximum consumption and minimum holdup are assumed for a worst-case as far as maximizing dose is concerned as represented by an individual supporting himself with a large garden and farm animals.

Data for aquatic exposure pathways are given in Table 9. The holdup time in this case is the time from release of the contaminant to the river to the time the individual or population is exposed. Average values from around $100-\mathrm{N}$ to Richland are given. These may vary slightly, depending on the exposure scenario. The average and maximum consumption/exposure parameters are defined as for terrestrial pathways. 
TABLE 8. Standard Terrestrial Exposure Pathway Data

\begin{tabular}{|c|c|c|c|c|c|c|c|}
\hline $\begin{array}{l}\text { Exposure } \\
\text { Pathway }\end{array}$ & $\begin{array}{l}\text { Growing Period } \\
\text { (Days) } \\
\end{array}$ & $\begin{array}{r}\text { Yield } \\
(\mathrm{kg} / \mathrm{m})\end{array}$ & $\begin{array}{l}\text { Irrigation } \\
\text { Rate } \\
(\mathrm{L} / \mathrm{m} / \text { month })\end{array}$ & $\frac{\text { Holdup }}{\text { Average }}$ & $\frac{\text { (days) }}{\text { Min imum }}$ & $\frac{\text { Consumpt io }}{\text { Average }}$ & $\frac{(\mathrm{kg} / \text { year })}{\text { Maximum }}$ \\
\hline Leafy Veg. & $9.0 \mathrm{E}+01$ & $1.5 E+00$ & $1.5 E+02$ & $1.4 \mathrm{E}+01$ & $1.0 E+00$ & $1.5 E+01$ & $3.0 E+01$ \\
\hline O.A.G. Veg. * & $9.0 E+01$ & $7.0 \mathrm{E}-01$ & $1.6 E+02$ & $1.4 E+01$ & $1.0 E+00$ & $1.5 E+01$ & 3.0 E+01 \\
\hline Root Veg. & $9.0 E+01$ & $4.0 E+\infty 0$ & $1.5 E+02$ & $1.4 E+01$ & $1.0 E+01$ & $1.2 E+02$ & $1.8 E+02$ \\
\hline Orch. Fruit & $9.0 E+01$ & $2.0 E+\infty 0$ & $1.5 E+02$ & $1.4 \mathrm{E}+01$ & $1.0 E+01$ & $6.4 E+01$ & $3.4 E+02$ \\
\hline Grain & $9.0 E+01$ & $1.0 E+00$ & $1.5 E+02$ & $1.4 E+01$ & $1.0 E+00$ & $8.0 E+01$ & $8.8 E+01$ \\
\hline Eggs & 9.0 E+01 & 8.4 E-01 & $1.5 E+02$ & $1.8 E+01$ & $1.0 E+00$ & $2.0 E+01$ & $3.0 E+01$ \\
\hline Milk & $3.0 E+01$ & $1.3 E+00$ & $1.5 E+02$ & $4.0 E+00$ & $1.0 E+\infty 0$ & $2.3 E+02$ & $2.7 E+02$ \\
\hline Beef & $9.0 E+01$ & $8.4 E-01$ & $1.4 E+02$ & $3.4 E+01$ & $1.5 E+01$ & $4.0 E+01$ & $4.0 E+01$ \\
\hline Pork & 9.0 E+01 & $8.4 \quad E-01$ & $1.4 E+02$ & $3.4 E+01$ & $1.5 E+01$ & $3.0 E+01$ & 4.0 E+01 \\
\hline Poultry & $9.0 E+01$ & 8.4 E-01 & $1.4 E+02$ & $3.4 E+01$ & $1.0 E+\infty 0$ & $8.5 E+00$ & $1.8 E+01$ \\
\hline External & & & $1.5 E+02$ & & & & \\
\hline
\end{tabular}

* Other above ground vegetables.

TABLE 9. Standard Aquatic Exposure Pathway Data

\begin{tabular}{|c|c|c|c|c|c|}
\hline \multirow{2}{*}{$\begin{array}{l}\text { Exposure } \\
\text { Pathway }\end{array}$} & \multirow{2}{*}{$\begin{array}{l}\text { Mixing } \\
\text { Ratio } \\
\end{array}$} & \multirow{2}{*}{$\begin{array}{l}\text { Holdup } \\
\text { (Days) }\end{array}$} & \multicolumn{3}{|c|}{ Usage } \\
\hline & & & Average & Maximum & Units \\
\hline Fish & $1.0+000$ & $1.0+000$ & $1.5+003^{\star}$ & $4.0+001$ & $(\mathrm{~kg} / \mathrm{yr})$ \\
\hline Drinking Water & $1.0+000$ & $1.0+000$ & $4.4+002$ & $7.3+002$ & $(L / y r)$ \\
\hline Shoreline & $1.0+000$ & $3.3-001$ & $1.7+001$ & $5.0+002$ & $(\mathrm{hr} / \mathrm{yr})$ \\
\hline Swimming & $1.0+000$ & $3.3-001$ & $1.0+001$ & $1.0+002$ & $(\mathrm{hr} / \mathrm{yr})$ \\
\hline Boating & $1.0+000$ & $3.3-001$ & $5.0+000$ & $1.0+002$ & $(\mathrm{hr} / \mathrm{yr})$ \\
\hline
\end{tabular}

* Total production from Columbia River; must be distributed among total population. 
Some caution must be used in setting up the population dose calculations. The populations exposed may vary with the scenario. For atmospheric releases, the entire $80 \mathrm{~km}(50 \mathrm{mile})$ population is used. However, for releases to the Columbia River, a more limited population can be assumed. While the $80 \mathrm{~km}$ population along the Columbia River is assumed for recreational activities on the river, only 50,000 Tri-Citians obtain drinking water from the river. Three areas of farmland are irrigated directly from the Columbia directly downstream of Hanford, 1) Frank lin County Irrigation District with production sufficient to feed only about 2,000 people with fresh produce, meat, and milk, 2) a few small farms at Ringold, mostly orchards, with some pasture land, and 3) a small acreage of hay near Burbank. The total fish harvest from the Columbia below Hanford totals $15,000 \mathrm{~kg}$, which can be prorated among any size population desired, since it is the amount consumed, not the number of people consuming it, that defines the collective dose.

Other required parameters that are needed to perform Hanford Site dose calculations are given in Table 10. For these parameters, if different values can be justified for specific uses, they may be used. Additional parameters needed to run the codes and control input and printing are described in the relevant code documentation.

\section{TABLE 10. General Exposure Pathway Data}

$\begin{array}{ll}\text { Individual external ground exposure time } & 4383 \mathrm{hr} / \mathrm{yr} \\ \text { Population external ground exposure time } & 2920 \mathrm{hr} / \mathrm{yr} \\ \text { Air submersion time } & 8766 \mathrm{hr} / \mathrm{yr} \\ \text { Inhalation time } & 8766 \mathrm{hr} / \mathrm{yr} \\ \text { Individual breathing rate, routine } & 250 \mathrm{~cm}^{3} / \mathrm{sec} \\ \text { Individual breathing rate, accident } & 350 \mathrm{~cm}^{3} / \mathrm{sec} \\ \text { Default aerosol particle size } & 1.0 \mathrm{micron} \\ \text { Average Columbia River flow rate } & 120,000 \mathrm{cfs}\end{array}$




\subsection{Groundwater Transport Parameters}

Adequate description of groundwater transport requires a conceptual mode 1 of a flow system before any numerical simulation can be done. The following items are necessary to specify a particular groundwater flow system to be simulated:

1) adoption of a grid system, subsequent location of lateral boundaries, and their types;

2) the time variation of the potential along the water boundaries;

3) the locations and flow rates of infiltration and their variations with time;

4) the surface that represents the aquifer bottom;

5) the initial potential distribution, time $=0$, for the simulation (Boundary and Initial Conditions); and

6) hydraulic conductivity and storage coefficient distributions.

The ability to simulate mass transport, once the results of the flow calculation all complete, also requires

7) distribution (retardation) coefficients; and

8) porosity data.

Part of the difficulty in defining standard parameters for Hanford hydrology is the inhomogeneity of the local geology. There is a significant difference between radionuclides released to unsaturated ground, deep basalts, or near surface unconfined aquifers. Care must be taken to properly define the conceptual model used.

The best defined data base for Hanford is for the unconfined aquifer. Definition and values of items 1 through 5 above, can be obtained for the VTT mode 1 from BNWL-1703 (Kipp 1976), and item 6 from BNWL-1706 (Cear lock 1976). General description of this near surface aquifer can be found in several references, the most readily available being the Hanford Environmental Impact 
Statement, ERDA-1538 (ERDA 1975). Staff of PNL's Hydrologic Systems Section, Water and Land Resources Department maintain current information on this aquifer.

Less information is readily available for the Hanford basalts. "An Analys is on the Use of Engineered Barriers for Isolation of Spent Fuel in Three Reference Geologies" (Cloninger 1981) uses Columbia Plateau Basalts as one of the reference geologies. The Assessment of Effectiveness of Geologic Isolation Systems (AEGIS) program at PNL is investigating the Hanford basalt as a possible reference site, and therefore preparing a Hanford data base (Petric 1981).

It is recommended that preparers of Hanford EIS's contact cognizant personne 1 rather than attempt an independent groundwater analysis.

\subsection{PROGRAM ACCESS}

Detailed instructions on the theory and use of each computer program are available in the relevant documentation. The dose programs are available for independent inspection and review on the BCSR UNIVAC, System B. File names and execute commands are listed in Table 11. Included in this table are the names of Battelle staff members familiar with the development, status, and use of each program. For programs that are not part of the standardized dose package, a reference and contact person are aiso given.

The programs are protected against unauthorized tampering (write protected) and certain subroutines are kept confidential. All standardized data files are also protected against unauthorized manipulation (read and write protected). Requests for information contained in the libraries should be directed to the authors. 
TABLE 11. Computer Program Access and Assistance

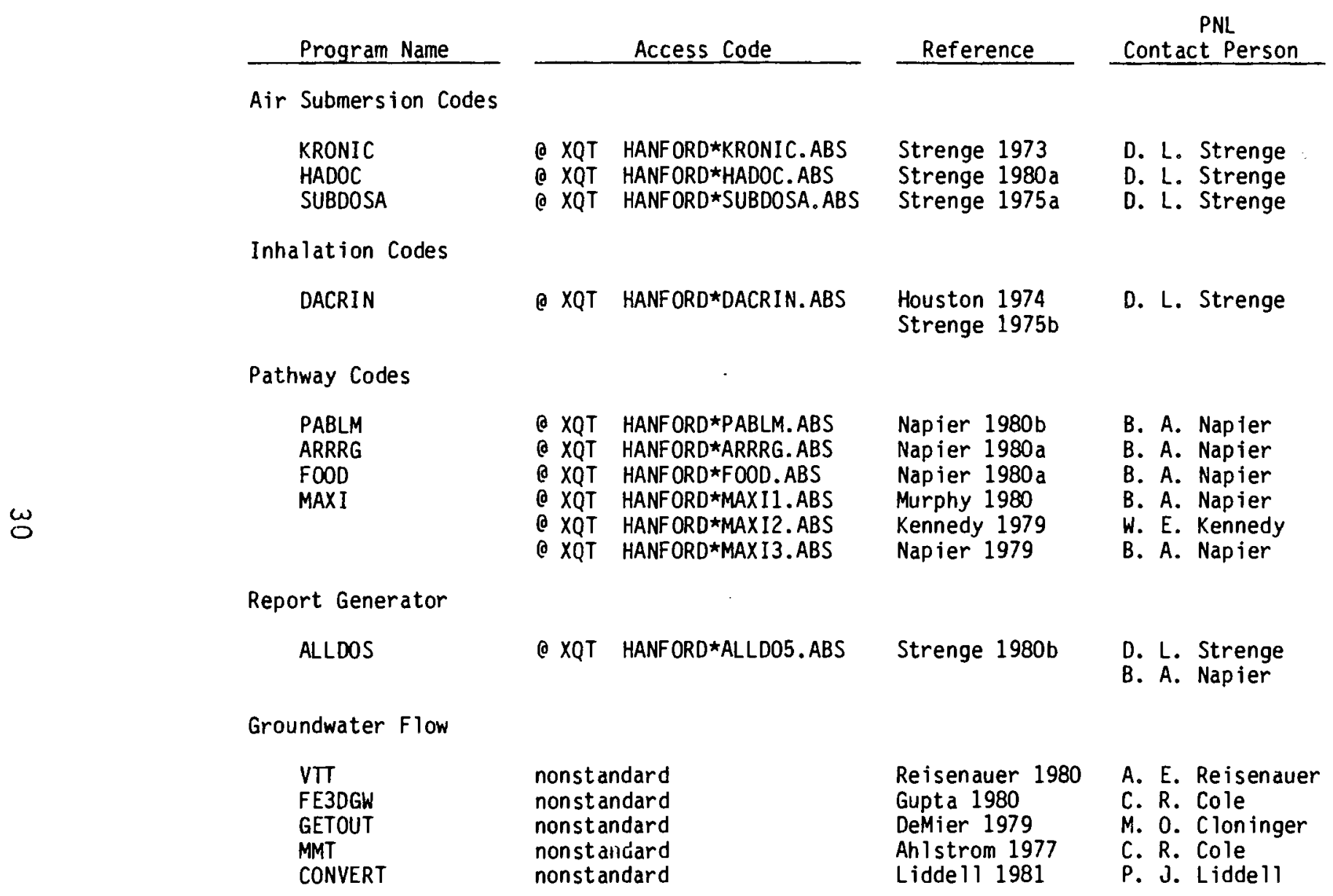




\subsection{REFERENCES}

Ah 1strom, S. W., et. a 1. 1977. Mu iticomponent Mass Transport Mode 1: Theory and Numerical Implementation. BNWL-2127, Pacific Northwest Laboratory, Richland, Washington.

Baker, D. A., G. R. Hoenes and J. K. Soldat. 1976. "F00D - An Interactive Code to Calculate Internal Radiation Doses from Contaminated Food

Products." BNWL-SA-5523. In Proceedings of Conference on Environmental Modeling and Simulation, Cincinnati, Ohio.

Cearlock, D. B., K. L. Kipp and D. R. Friedrichs, 1975. The Transmissivity Interactive Calculation Routine--Theory and Numerical Implementation. BNWL-1706, Pac if ic Northwest Laboratory, Richland, Washington.

Cloninger, M. 0., and C. R. Cole. 1981. An Analys is on the Use of Engineered Barriers for Isolation of Spent Fuel in Three Reference Geologies. PNL-3530, Pacific Northwest Laboratory, Richland, Washington.

DeMier, W. V., M. O. Cloninger, H. C. Burkholder and P. J. Liddell. 1979. GETOUT-A Computer Program for Predicting Radionuclide Decay Chain Transport Through Geologic Media. PNL-2970, Pacific Northwest Laboratory, Richland, Washington.

Fuquay, J. J., C. L. Simpson and W. T. Hinds. 1964. Estimates of Ground Level Air Exposures Resulting from Protracted Emissions from 70 -Meter Stacks at Hanford. HW-80204, Richland, Washington.

Gupta, S. K., C. R. Cole and F. W. Bond. 1980. Finite-Element ThreeDimensional Groundwater (FE3DGW) Flow Mode 1--Formulation, Program Listings, and Users' Manue 1. PNL-2939, Pacific Northwest Laboratory, Richland, Washington.

Houston, J. R., D. L. Strenge and E. C. Watson. 1974. DACRIN - A Computer Program for Calculating Organ Dose from Acute or Chronic Radionuclide Inhalation. BNWL-B-389, Pacific Northwest Laboratory, Richland, Washington.

Houston, J. R., and P. J. Blumer. 1979. Environmental Surveillance at Hanford for CY-1978. PNL-2932, Pacific Northwest Laboratory, RichTand, Washington.

International Commission on Radiological Protection (ICRP 1959). Report of ICRP Committee II on Permissible Dose for Internal Radiation. ICRP Publication 2, Pergamon Press, New York.

ICRP Task Group for Committee II. 1966. "Task Group on Lung Dynamics for Committee II of the ICRP." Health Physics (12):173. 
Kennedy, W. E., Jr, E. C. Watson, G. R. Hoenes and B. A. Napier. 1979. A Method for Determining Acceptable Residual Radioactive Contamination Leve1s. PNL-SA-7495, Presented at the 24th Annual Meeting of the Health Physics Society, Philadelphia, Pennsylvania.

Kipp, K. L., A. E. Reisenauer, C. R. Cole and C. A. Bryan. 1976. Variable Thickness Transient Groundwater Flow Model: Theory and Numerical Imp lentation. BNWL-1703, Pac ific Northwest Laboratory, Richland, Washington.

Lidde 11, P. J. 1981. User Manual for CONVERT. PNL-3239, Pacific Northwest Laboratory, Richland, Washington (in press).

McCormack, W. D. 1981. The Hanford Dose Overview Program. PNL-3777, Pacific Northwest Laboratory, Richland, Washington (in press).

Murphy, E. S., and G. M. Holter. 1980. Technology, Safety and Costs of Decommissioning a Reference Low-Level Waste Burial Ground. NUREG/CR-0570, Pacific Northwest Laboratory, Richland, Washington.

Napier, B. A., G. R. Hoenes, W. E. Kennedy, Jr. and E. C. Watson, 1979. The Maximum Annual Dose Resulting from Residual Radioactive Contamination. PNL-SA-7496, Presented at the 24th Annual Meeting of the Health Physics Society, Philadelphia, Pennsylvania.

Napier, B. A., R. L. Roswe 11, W. E. Kennedy, Jr. and D. L. Strenge. 1980 a. ARRRG and FOOD - Computer Programs for Calculating Radiation Dose to Man from Radionuclides in the Environment. PNL-3180, Pac if ic Northwest Laboratory, Richland, Washington.

Napier, B. A., W. E. Kennedy, Jr. and J. K. Soldat. 1980b. PABLM - A Computer Program to Calculate Accumulated Radiation Dose from Radionuclides in the Environment. PNL-3209, Pac ific Northwest Laboratory, Richland, Washington.

Pasquil1, F. 1962. Atmospheric Diffusion. D. Van Nostrand Co., LTD.

Petrie, G. M., et. al. 1981. Geologic Simulation Model for a Hypothetical Site in Basalts of the Columbia Plateu. PNL-3542, Pacific Northwest Laboratory, Richland, Washington.

Reisenauer, A. E. 1979. Variable Thickness Transient Groundwater Flow Model ( 3 Volumes). PNL-3160, Pacific Northwest Laboratory, Richland, Washington.

Sagendorff, J. F., and J. T. Gol1. 1977. X0QD0Q Program for the Meteorological Evaluation of Routine Effluent Releases at Nuclear Power Stations. NUREG-0324, U.S. Nuc lear Regu Tatory Commission, Washington, D.C.

Schreckhise, R. G. 1980. Simulation of the Long-Term Accumulation of Radionuclides in Crop Plants. PNL-2636, Pacific Northwest Laboratory, Richland, Washington. 
Silviera, D. J., M. A. Harwe 11, B. A. Napier, J. T. Zellmer and G. L. Benson. 1980. A Short Description of the AEGIS Approach. PNL-3398, Pacific Northwest Laboratory, Richland, Washington.

Slade, D. H., ed. 1968. Meteorology and Atomic Energy. USAEC Division of Technical Information Extension, Oak Ridge, Tennessee.

Soldat, J. K., and R. D. Harr. 1971. "Radiation Dose Mode1." In HERMES - A Digital Computer Code for Estimating Regional Radiological Effects from the Nuclear Power Industry. USAEC Report HEDL-TME-71-68, Hanford Engineering Development Laboratory, Rich land, Washington.

Soldat, J. K., N. M. Robinson and D. A. Baker. 1974. Models and Computer Codes for Evaluating Environmental Radiation Doses. BNWL-1754, Pacific Northwest Laboratory, Richland, Washington.

Strenge, D. L., and E. C. Watson. 1973. KRONIC - A Computer Program for Calculating Annual Average External Doses from Chronic Atmospheric Releases of Radionuclides. BNWL-B-264, Pacific Northwest Laboratory, Richland, Washington.

Strenge, D. L., and R. A. Peloquin. 1980a. HADOC - A Computer Code for Calculation of External and Inhalation Doses from Acute Radionuclide Releases. Draft PNL-3503, Pacific Northwest Laboratory, Richland, Washington.

Strenge, D. L., B. A. Napier, R. A. Peloquin and M. G. Zimmerman. 1980b. ALLDCS - A Computer Program for Calculation of Radiation Doses from Airborne and Waterborne Releases. PNL-3524, Pacific Northwest Laboratory, Richland, Washington.

Strenge, D. L., E. C. Watson and J. R. Houston. 1975a. SUBDOSA - A Computer Program for Calculating External Doses from Accidental Atmospheric Releases of Radionuclides. BNWL-B-351, Pacific Northwest Laboratory, Richland, Washington.

Strenge, D. L. 1975b. DACRIN - Modification for Gastrointestinal Tract Dose. BNWL-B-399, SUPP, Pacific Northwest Laboratory, Richland, Washington.

Sutton, 0. G. 1953. Micrometeorology. McGraw-Hil1 Book Company, New York.

U.S. Atomic Energy Commission. 1974. Regulatory Guide 1.3, "Assumptions Used for Evaluating the Potential Radiological Consequences of a Loss of Coolant Accident for Boiling Water Reactors," USAEC Directorate of Regulatory Standards, Washington, D.C.

U.S. Atomic Energy Commission. 1974. Regulatory Guide 1.4, "Assumptions Used for Evaluating the Potential Radiological Consequences of a Loss of Coolant Accident for Pressurized Water Reactors," USAEC Directorate of Regulatory Standards, Washington, D.C. 
U.S. Energy Research and Development Administration. 1975. Waste Management Operations: Hanford Reservation. ERDA-1538, Washington, D.C.

Wallace, R. W., et. al. 1980. Topical Report on Release Scenario Analys is of Long-Term Management of High-Level Defense Waste at the Hanford Site. PNL-3363, Pacific Northwest Laboratory, Richland, Washington.

Washburne, J. F., F. E. Kaszeta, S. C. Simmons and C. R. Cole. 1980. Multicomponent Mass Transport Mode 1: A Model for Simulating Migration of Radionuc lides in Groundwater. PNL-3179, Pacific Northwest Laboratory, Richland, Washington.

Yandon, K. E., and D. K. Landstrom. 1979. Supplemental Report on Population Est imates for Hanford High-Leve 1 Defense Waste Draft Programmatic Environmental Impact Statement. PNL-3128, Pacific Northwest Laboratory, Richland, Washington.

Yandon, K. E., J. S. Burlison, and R. G. Rau. 1980. Supplemental Report on Population Est imates for Hanford Low-Level Waste Draft Programmatic Environmental Impact Statement. PNL-3507, Pacific Northwest Laboratory, Richland, Washington. 
APPENDIX A

RADIATION DOSE TERMINOLOGY AND DEFINITIONS

A-1 


\section{APPENDIX A}

\section{RADIATION DOSE TERMINOLOGY AND DEF INITIONS}

The following terminology and definitions apply for the radiation doses calculated by the Hanford standardized dose programs:

Routine Release (Chronic Release). A release of radionuclides to the atmosphere, to a body of water, or to the ground that occurs over a long time span (e.g., months to years) at a constant rate.

Acute Release. A release of radionuclides, to the atmosphere or to a body of water, that is of short duration (usually less than eight hours). Accident analyses are usually based on acute releases.

Organs of Reference. The internal organs of the human body for which radiation doses are calculated. For Hanford Site studies, these usually include the total body, thyroid glands, lungs, bone, and the lower large intestine (LLI) of the GI-tract. The total body is the head and trunk of the human body, including active blood forming organs, lenses of eyes, and gonads. Exposure Pathways. The potential routes by which people may be exposed to radionuclides or radiation. Different release types lead to different exposure pathways. The standardized Hanford dose programs each handle selected exposure pathways, therefore, it is often necessary to use more than one program to fully model a release scenario. The possible exposure pathways include:

1) Air submersion. External irradiation by airborne of radionuclides.

2) Water immersion. External irradiation while swimming or boating in or on contaminated water.

3) Direct irradiation. External irradiation from radionuclides deposited on soil or sediment from contaminated air or water.

4) Inhalation. Internally deposited radionuclides from breathing contaminated air.

5) Ingestion. Internally deposited radionuclides from eating contaminated plant or animal products or from drinking contaminated water. 
External irradiation refers to a dose received from radionuclides outside the body, and internal irradiation refers to a dose from radionuclides taken into the body. The various exposure pathways are illustrated in Figure A.1.

Maximumally Exposed Individual. An hypothetical person with assumed dietary habits and living circumstances tend to result in his receiving the maximum radiation dose to an organ of reference. Maximized exposure pathway parameters are used.

Radiation Dose. The quantity used to express the absorbed dose from all radiations on a common scale in units of rem. This is properly called the Absorbed Radiation Dose Equivalent. It is defined as the product of the absorbed dose (in rads), a quality factor intended to allow for the effect of the microscopic distribution of absorbed energy, and other modifying factors as defined by the International Commission on Radiological Protection (ICRP). Population Dose. The summation of radiation dose equivalents received by all individuals in the population of concern. It is calculated by multiplying the dose to the average individual by the population distribution for the site listed. Average parameter values are used for the exposure pathways. This is more properly referred to as a "collective dose", and has units of man-rem. First-year Dose. The radiation dose equivalent accumulated during the first year of exposure.

Dose Commitment. The dose equivalent accumulated over a specific number of years from radionuclides deposited in the body from the various exposure pathways during the first year. This is properly called a committed Radiation Dose Equivalent. It is usually calculated for a 50-yr period, and is referred to as a 50-yr Dose Commitment.

Accumulated Dose. The radiation dose equivalent over an extended period of time from continuous exposure to levels of environmental contamination, which may or may not be constant, for the entire period.

Annual Dose. The radiation dose equivalent calculated during any year following the start of continuous exposure. It is the sum of the dose received by an organ of reference during the year of interest from all exposure pathways and the dose received that year from radionuclides deposited in the organ of reference during the previous years. 
Maximum Annual Dose. The largest of the 50 annual doses calculated to occur during the 50 years following the start of continuous exposure to a variable source term.

Biological Half-time. The time required for the body to eliminate half of any substance by normal biological processes.

Translocation Classes $\mathrm{D}, \mathrm{W}$, and $\mathrm{Y}$. Radionuclides are classified according to the rate at which they are transported by body fluids from the lung to the blood and G.I. tract after inhalation. The three classifications used are: Class $D$ materials, with a maximum clearance half-life of less than 1 day; Class $W$ materials, with a maximum clearance half-life ranging from a few days to a few months; and Class $Y$ materials, with a maximum clearance half-life of from 6 months to a few years (ICRP 1966). 


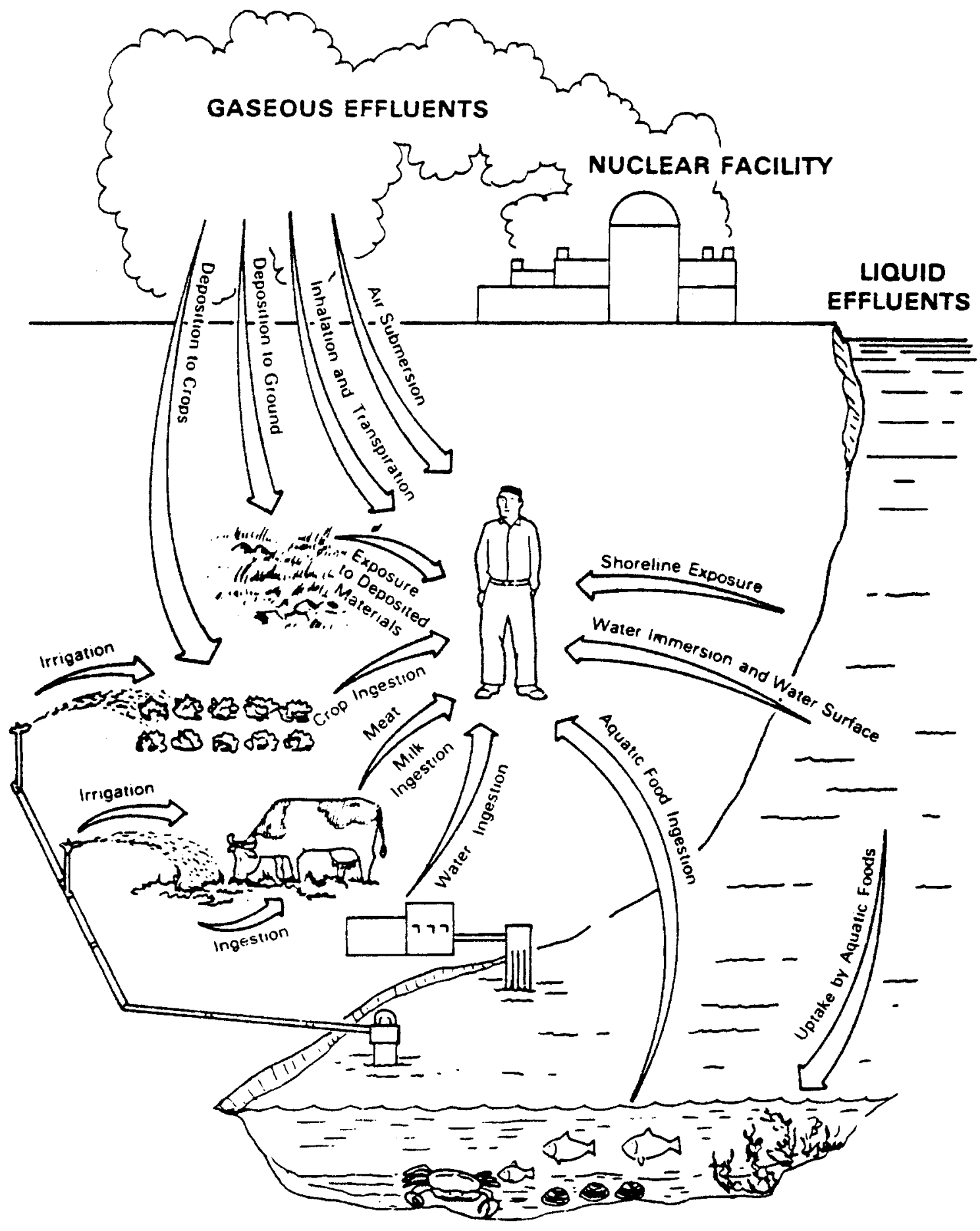

FIGURE A.1. Exposure Pathways to Man 


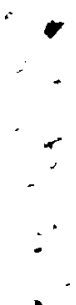




\section{DISTRIBUTION}

\section{$\underline{\text { OFFSITE }}$}

A. A. Churm

DOE Chicago Patent Group

9800 South Cass Avenue

Argonne, IL 60439

27 DOE Technical Information Center

V. G. Trice

DOE Office of Nuclear Waste

Management

Washington, D.C. 20545

J. W. Rowen

DOE Office of Nuclear Waste

Management

Washington, D.C. 20545

E. F. Mastal

DOE Office of Nuclear Waste Management

Washington, D.C. 20545

R. Scott

DOE Office of Nuclear Waste Management

Washington, D.C. 10545

\section{ONSITE}

1 DOE Richland Operations Office

H. E. Ransom
2 Hanford Engineering Development Laboratory

G. D. Carpenter

J. T. Denovan

4 Rockwe 11 Hanford Operations

A. R. Hawk ins (2)

D. E. Wood

D. D. Wodr ich

UNC Nuclear Industries

P. A. Carlson

79 Pacific Northwest Laboratory

S. M. Brown

P. E. Bramson

J. B. Brown

F. H. Dove

K. E. Harding (4)

G. R. Hoenes

W. E. Kennedy

W. D. McCormack

M. A. Mueller (20)

B. A. Napier (30)

R. A. Peloquin

A. E. Reisenauer

J. V. Robinson (4)

R. G. Schreckhise

J. K. Soldat

D. L. Strenge

B. A. Vaughan

E. C. Watson

Technical Information Library (5)

Publishing Coordination (2) 
